\title{
Phosphorus Solubility from Rock Phosphate Mixed Compost with Sulphur Application and Its Effect on Yield and Phosphorus Uptake of Wheat Crop
}

\author{
Kashif Khan, Muhammad Sharif, Imran Azeem, Ibadullah, Adnan Anwar Khan, Sajid Ali, \\ Imran Khan, Aamir Khan
}

Department of Soil and Environmental Science, Faculty of Crop Production Sciences, The University of Agriculture, Peshawar, Pakistan

Email: kashifkhanses@gmail.com

How to cite this paper: Khan, K., Sharif, M., Azeem, I., Ibadullah, Khan, A.A., Ali, S., Khan, I. and Khan, A. (2017) Phosphorus Solubility from Rock Phosphate Mixed Compost with Sulphur Application and Its Effect on Yield and Phosphorus Uptake of Wheat Crop. Open Journal of Soil Science, 7, 401-429.

https://doi.org/10.4236/ojss.2017.712028

Received: October 27, 2017

Accepted: December 19, 2017

Published: December 22, 2017

Copyright $\odot 2017$ by authors and Scientific Research Publishing Inc. This work is licensed under the Creative Commons Attribution International License (CC BY 4.0).

http://creativecommons.org/licenses/by/4.0/

\section{(c) (i) Open Access}

\begin{abstract}
A field experiment was conducted to determine the effect of sulphur application with Rock phosphate mixed compost on phosphorus (P) solubility and its effect on yield and $\mathrm{P}$ uptake of wheat crop. The experiment was laid out in randomized complete block design (RCBD) with three replications at the research farm of The University of Agriculture Peshawar. The experiment was conducted during rabi 2015-16 with plot size of $3 \mathrm{~m} \times 5 \mathrm{~m}$. Nitrogen, phosphorus and potassium were applied at the rate of 120,90 and $60 \mathrm{~kg} \cdot \mathrm{ha}^{-1}$ in the form of urea, compost, or single super phosphate and potassium sulphate, respectively. Elemental sulphur was applied at the rate of 10,20 and $30 \mathrm{~kg} \cdot \mathrm{ha}^{-1}$ at the time of sowing. Results showed that sulphur applied with compost significantly improved wheat yield and yield components, soil organic matter, soil total $\mathrm{N}$ and AB-DTPA extractable P contents, plant $\mathrm{N}$ and $\mathrm{P}$ concentrations and their uptake, plant micronutrients concentration and their uptakes. No significant changes were noted in soil $\mathrm{pH}, \mathrm{ECe}$ and lime contents. Maximum grain yield of $4076 \mathrm{~kg} \cdot \mathrm{ha}^{-1}$, total dry matter yield $9721 \mathrm{~kg} \cdot \mathrm{ha}^{-1}$, straw yield $5644 \mathrm{~kg} \cdot \mathrm{ha}^{-1}$, plant height $98.3 \mathrm{~cm}$, spike length $11.2 \mathrm{~cm}$, grain per spike 61.0, thousand grain weight $50.2 \mathrm{~g}$ were recorded on the application of $\mathrm{S}$ at the rate $20 \mathrm{~kg} \cdot \mathrm{ha}^{-1}$ with compost. The highest soil organic matter content of $1.41 \%$ was found for the application of $\mathrm{S}$ at the rate of $10 \mathrm{~kg} \cdot \mathrm{ha}^{-1}$ with compost. Maximum soil total $\mathrm{N}$ content of $1756 \mathrm{mg} \cdot \mathrm{kg}^{-1}$ and $\mathrm{P} 5.7 \mathrm{mg} \cdot \mathrm{kg}^{-1}$ were observed by the application of double recommended S with compost. Plant $\mathrm{N}$ uptakes of $125.7 \mathrm{~kg} \cdot \mathrm{ha}^{-1}$, and $\mathrm{P}$ uptake of $17.5 \mathrm{~kg} \cdot \mathrm{ha}^{-1}$, were maximum with application of compost and S @ $20 \mathrm{~kg} \cdot \mathrm{ha}^{-1}$. Highest plant uptake of Fe 0.56
\end{abstract}


$\mathrm{kg} \cdot \mathrm{ha} \mathrm{a}^{-1}, \mathrm{Zn} 0.41 \mathrm{~kg} \cdot \mathrm{ha}^{-1}, \mathrm{Cu} 0.16 \mathrm{~kg} \cdot \mathrm{ha}^{-1}$ and $\mathrm{Mn} 0.93 \mathrm{~kg} \cdot \mathrm{ha}^{-1}$ were found by the application of full recommended $\mathrm{S}$ with compost. Results suggested that $\mathrm{S}$ at the rate of $20 \mathrm{~kg} \cdot \mathrm{ha}^{-1}$ application with compost prepared from farm yard manure and rock phosphate proved better combination to enhance wheat yield, yield components and nutrients uptakes of wheat crop.

\section{Keywords}

Phosphorus Solubility, Rock Phosphate, Compost, Sulphur, Wheat Crop

\section{Introduction}

Phosphorous $(\mathrm{P})$ is the succeeding important macronutrients following nitrogen $(\mathrm{N})$ indispensable for plant growth [1] and has key function in numerous metabolic processes of plant and animals life. It has functions in metabolic pathways of biosynthesis and degradation and structural nature in macromolecules [2]. It also plays a very important role in several physiological processes such as energy storage, respiration, photosynthesis, and cell enlargement/division. It is an essential structural constituent of various bio chemicals such as nucleic acid (DNA and RNA enzymes and coenzymes). Phosphorus is linked with early maturity of crops and helps in the stimulation of root growth. It also helps to prevent the plants from different diseases. It strengthens the straw by preventing them from lodging [3].

Among different factors accountable for low yield, fertilizer management may be of much importance [4]. It has also been shown in various findings that nearly $90 \%$ of Pakistan soils are scarce in phosphorous content [5]. Due to high cost of phosphate fertilizers, substituted sources are needed. For this purpose rock phosphate (RP) can be used practically which has been known as an important substitute source for $\mathrm{P}$ fertilizers has received important consideration in recent years. Rock phosphate contains naturally of the group containing apatite having high amount of phosphate minerals. It mostly produces phosphatic fertilizers used for agricultural purposes. Compost manure and RP are the chief and locally available sources of phosphorus [6]. The solubility of RP is still narrow while on the other hand the concentration of $\mathrm{P}$ is very low in compost manure [7] [8] [9]. Conversely, by enhancing solubilization of rock phosphate and $\mathrm{P}$ concentration in compost manure can handle the concentration of soil P. Availability of phosphorus can be increased when RP are applied with organic manure because it enhances rock phosphate dissolution in the soil. During the process of composting, organic acids are formed which create favorable environment for solubilization of $\mathrm{P}$ thus reducing the $\mathrm{pH}$ values and improving other properties. $\mathrm{RP}$ can be used as a $\mathrm{P}$ source in many crops in relationship with organic manure and phosphate solubilizing microorganism [10]. During the decomposition of organic materials, the organic acids produced provide protons for RP dissolution 
[11]. To increase the productivity of crops fertilizers are very important especially in wheat crop. For good quality and better yield of crops, micronutrients apart from $(\mathrm{N}, \mathrm{P}, \mathrm{K})$ play a major role in balanced managements of nutrients. Fertilizers responses to crops may differ greatly due to soil and climatic conditions. Generally, Pakistani soils are high in $\mathrm{pH}$, light to medium in texture and calcareous in nature.

Sulfur is one of the imperative nutrients for plant growth and plant tissue containing $0.2 \%$ to $0.5 \%$ on dry matter basis. [12] showed that requirements of sulphur is quite similar that of phosphorus. It is a building block of protein help in the formation of chlorophyll [13]. The problems of calcareous soils can be resolve with the application of different sulphur fertilizers. Hence, the importance has amplified in by means of elemental $S$ to develop the solubility of plant nutrients especially $\mathrm{P}$. The elemental sulphur applied to soil is oxidized in to $\mathrm{H}_{2} \mathrm{SO}_{4}$ $\left(2 \mathrm{~S}+3 \mathrm{O}_{2}+2 \mathrm{H}_{2} \mathrm{O} \rightarrow 2 \mathrm{H}_{2} \mathrm{SO}_{4}\right)$. This $\mathrm{H}_{2} \mathrm{SO}_{4}$ so produced is beneficial to make phosphorus and micronutrients more available to plants, supplying of $\mathrm{SO}_{4}$ to plants and decreasing the $\mathrm{pH}$ of the soil. [14] found that by $\mathrm{S}$ application dry weight of plant, phosphorus concentration and nutrients uptake were increased and soil $\mathrm{pH}$ was reduced $0.11-0.37$ unit. In Pakistan, sulphur is not measured, in fertilizers as plant nutrients and in the country; information about sulphur condition in soil is quite low. In period of fast growth during early spring, high amount of sulphur is required for wheat plant due to slow release of sulphur from soil organic matter [15]. Sulphur fertilizers application considerably increased wheat yield [16] [17] [18] and rapeseed [19]. [20] showed that grain yield and grain per spike of barley significantly increased by foliar sulphur application. Sulphur is important for many physiological process in plant such as, synthesis of certain vitamins (Biotin and Thiomine), synthesis of co-enzyme A synthesis of S containing amino acids (Cysteine, Cystine and Methionine), and in the metabolism of, fats, carbohydrates and protein. [21] showed that deficiency of sulphur change composition of grain by falling grain sulphur and restricting the structure of proteins enriched with sulphur. Due to poor S flour status, the dough extensibility and baking quality can be restricted [22].

Compost contains lot of nutrients having high content of organic matter. By using compost, the properties of soil such as chemical and physical can be enhanced, which may increase crop yield ultimately. [23] showed that physical properties like porosity, water permeability, hydraulic conductivity, void ratio and bulk density were extensively improved with compost of farmyard manure in combination with different fertilizers. These properties of soil can also be improved by the application of chopped salt grass, rice straw and wheat straw. The paddy yield, biomass, plant height and tillering, were drastically improved [24]. [25] also proved that dissimilar types of compost like water hyacinth, dry leaves, mixed weeds, and barseem increased yields of wheat, and rice, gram and green beans. By the application of urban compost or FYM or green manure @ 12.5 $\mathrm{kg} \cdot \mathrm{ha}^{-1}$ straw and grain yields of rice were amplified in addition through NPK. Generally, manure fertilizers such as urban compost, green manure and FYM, at 
the @ $12.5 \mathrm{t} \cdot \mathrm{ha}^{-1}$ beside with different inorganic sources could make best use of the rice yield and uptake of nutrients compared to suggested levels of fertilizers exclusive of any manure [26].

Wheat (Triticum aestivum L.) is a winter self-pollinated crop, belongs to family Poacceae tribe Hordeae is the world's leading cereal crop both in area and production and feeding about one third of the whole world population. Pakistan is the 8th largest wheat producing country of the world. It is a vital staple food inside the country. Wheat is one of the mainly plentiful sources of protein and energy for the world population. It is a most important component in many foods such as breakfast cereals, cakes, doughnuts and roll, pies, pastries, bread, pancakes and other alcoholic beverages. It has been reported that $100 \mathrm{~g}$ of spring wheat contains about $12.2 \mathrm{~g}$ of fiber, $71 \mathrm{~g}$ of carbohydrates, $1.54 \mathrm{~g}$ of fats, $12.6 \mathrm{~g}$ of protein, vitamins in trace amount and a massive quantity of nutrients [27]. In 2015-2016, wheat was cultivated on $9.25 \mathrm{~m}$ ha in $\mathrm{Pa}$ kistan with a production of $25.45 \mathrm{~m}$ tons, while in Khyber Pakhtunkhwa wheat was cultivated on $0.78 \mathrm{~m}$ ha with a production of $1.35 \mathrm{~m}$ tons [28]. Keeping in observation the significance of sulphur and compost, this experiment was designed to investigate the effect of S applied with compost prepared with RP on yield and uptake of $\mathrm{P}$ by wheat crop.

\section{Materials and Methods}

A field experiment was conducted at research farm of The University of Agriculture, Peshawar during Rabi season 2015-2016 to study the effect of phosphorous solubility from compost prepared with FYM and RP as influenced with sulphur and its effect on yield and $\mathrm{P}$ uptake of wheat crop. The experiment was laid out in randomized completely block design (RCBD) with three replications. Wheat variety (Atta Habib) was sown with seed rate of $100 \mathrm{~kg} \cdot \mathrm{ha}^{-1}$. There were 8 treatments in the experiment and the plot size was kept $5 \mathrm{~m}$ long and $3 \mathrm{~m}$ wide containing ten rows of plants. The row to row distance of wheat plants was kept $30 \mathrm{~cm}$ apart. Sulphur and compost prepared from rock phosphate (RP) and farm yard manure (FYM) were applied at the time of sowing. Sulphur was applied at three different levels as 10, 20 and $30 \mathrm{~kg} \cdot \mathrm{ha}^{-1}$ [23]. Compost was applied on the basis of its $\mathrm{P}$ content. The $\mathrm{N}$ content of compost was adjusted and the rest was fulfilled from urea. Nitrogen, phosphorus and potassium were applied the rate of $120,90 \mathrm{~kg} \cdot \mathrm{ha}^{-1}$ and $60 \mathrm{~kg} \cdot \mathrm{ha}^{-1}$ in the form of urea, compost or single super phosphate and potassium sulphate respectively. Nitrogen was applied in three split doses, while all phosphorus and potassium doses were applied at the time of sowing. Data recorded were statistically analyzed using ANOVA technique and means were compared using LSD test at 5\% level of probability. Treatments combinations used in the experiment are given as follows;

1) Control (No fertilizers)

2) $\mathrm{N}$ and $\mathrm{K}$ fertilizers as basal dose applied to all treatments except control.

3) N, P and $\mathrm{K}$ at the rate of 120,90 and $60 \mathrm{~kg} \cdot \mathrm{ha}^{-1}$ 
4) Compost @ recommended level of $P$

5) N,P and K + Sulphur @ $20 \mathrm{~kg} \cdot \mathrm{ha}^{-1}$

6) Compost $+\mathrm{S} @ 10 \mathrm{~kg} \cdot \mathrm{ha}^{-1}$

7) Compost $+\mathrm{S} @ 20 \mathrm{~kg} \cdot \mathrm{ha} \mathrm{a}^{-1}$

8) Compost $+\mathrm{S} @ 30 \mathrm{~kg} \cdot \mathrm{ha}^{-1}$

\subsection{Laboratory Study}

\subsubsection{Soil pH}

Ten $g$ soil sample was taken in a shaking bottle. $50 \mathrm{ml}$ distilled water was added and soil water suspension (1:5) was made. The suspension was then shaked for 30 minutes on horizontal shaker. The suspension was then brought for $\mathrm{pH}$ meter. With the help of $\mathrm{pH}$, meter $\mathrm{pH}$ of the soil was determined. Before measuring the $\mathrm{pH}$ meter was calibrated with standard buffers of 4.0 and 10.0 as method shown by [29].

\subsubsection{Soil EC(e)}

Electrical conductivity of the soil suspension was determined by adding ten $g$ soil with $50 \mathrm{ml}$ distilled water and soil water suspension (1:5) was made. EC of the suspension was determined by EC meter [30]. Before taking readings of the samples with known concentration of KCL solution the ECe meter was calibrated.

\subsubsection{Soil Organic Matter Content}

Soil organic method was determined by the method of [7]. In a conical flask, $1 \mathrm{~g}$ of soil was taken by adding $10 \mathrm{ml}$ of $1 \mathrm{~N} \mathrm{~K}_{2} \mathrm{Cr}_{2} \mathrm{O}_{7}$ solution and $20 \mathrm{ml}$ of concentrated $\mathrm{H}_{2} \mathrm{SO}_{4}$. It was then set aside for 30 minutes to complete the reaction. The volume was then reached up to $200 \mathrm{ml}$ by adding distilled water. The suspension was then filtered through what man-42 filter paper, and 2 - 3 drops of orthophenophthaline was added and titrated against $\mathrm{Fe}_{2} \mathrm{SO}_{4} \cdot 7 \mathrm{H}_{2} \mathrm{O}$ of $0.5 \mathrm{~N}$, end was recorded when dark brown color was observed.

\subsubsection{Soil Lime Content}

By acid neutralization method lime content of soil was determined [31]. In this method, soil of $5 \mathrm{~g}$ was taken in conical flask, and then $50 \mathrm{ml}$ of $\mathrm{HCl}$ of $0.25 \mathrm{~N}$ was added to it. For 5 minutes, flask was put on hot plate and was allowed to cool for some time. Then 2 - 3 drops of phenolphthalein indicator was supplemented to the flask and titrate against $0.25 \mathrm{~N} \mathrm{NaOH}$. The titration was completed when pink color appeared.

\subsubsection{Soil Total Nitrogen Content}

Total nitrogen of the soil was determined by the Kjeldhal method of [32]. Soil sample of $0.2 \mathrm{~g}$ and $1.1 \mathrm{~g}$ digestion mixture was taken in a digestion tube. Then concentrated sulphuric acid of $3 \mathrm{ml}$ was added. After that 2 - $3 \mathrm{ml}$ distilled water was added. At $350^{\circ} \mathrm{C}$ digestion tube was kept in a digestion block for $3-4$ hours. The digestion method was continued till greenish color appeared. When green- 
ish color appeared the tubes was removed from digestion block and for some time the solution was allowed to cool. Then with distilled water the solution was diluted to $100 \mathrm{ml}$. In a distillation flask, $20 \mathrm{ml}$ sample was taken along with $4 \mathrm{ml}$ of $40 \% \mathrm{NaOH}$ for distillation process. For collecting evaporated extract, boric acid of $5 \mathrm{ml}$ mixed indicator was taken in $100 \mathrm{ml}$ conical flask until the volume reached up to $65 \mathrm{ml}$. The distillate of $65 \mathrm{ml}$ was then analyzed for total nitrogen by titrate it against $0.005 \mathrm{~N} \mathrm{HCl}$ until pink color appeared and then reading was noted. Blank sample was also run which contain $20 \mathrm{ml}$ distilled water as a substitute of soil sample.

\subsubsection{Soil AB-DTPA Extractable P}

Phosphorus content of soil was determined by extracting it with AB-DTPA extracting solution as described by [33]. In a flask soil of $15 \mathrm{~g}$ was taken and solution of $30 \mathrm{ml}$ AB-DTPA extracting was added to it. The sample was then kept on a horizontal shaker and shaked the samples for 15 minutes. With the help of watt man-42 filter paper suspension was filtrated in to small bottles. Then $1 \mathrm{ml}$ extract was taken from filtrate and transferred it into $25 \mathrm{ml}$ volumetric flask. Ascorbic mix reagent of $5 \mathrm{ml}$ along with distilled water of $4 \mathrm{ml}$ of distilled water and adjusted the volume up to $25 \mathrm{ml}$ by adding distilled water. The flask was then kept in dark for about 15 minutes in order to developed blue color. For calibration of spectrophotometer, then absorption curve was developed on spectrophotometer for $0,2,4,6,8$ and $10 \mathrm{ppm}$ standard solution. With the help of spectrophotometer, the samples were analyzed. $\mathrm{Fe}, \mathrm{Zn}, \mathrm{Mn}$, and $\mathrm{Cu}$, concentration were determined through atomic absorption spectrophotometer.

\subsubsection{Plant Nitrogen Concentration}

Plant nitrogen concentration was determined by the Kjeldhal method of [32]. Plant sample of $0.2 \mathrm{~g}$ along with digestion mixture of $1.1 \mathrm{~g}$ was taken in a digestion tube. Concentrated sulphuric acid of $3 \mathrm{ml}$ and distilled water $2-3 \mathrm{ml}$ was added. At $350^{\circ} \mathrm{C}$ digestion tube was kept for $3-4$ hours in a digestion block. The process of digestion was continued until greenish color appeared. When greenish color appeared the tubes was detached from digestion block and was allowable to cool for some time. In $100 \mathrm{ml}$ distilled water the solution was diluted. In a digestion flask sample of $10 \mathrm{ml}$ was taken beside with $4 \mathrm{ml}$ of $40 \% \mathrm{NaOH}$ for distillation process. Mixed indicator boric acid of $5 \mathrm{ml}$ was taken in conical flask of $100 \mathrm{ml}$ for collecting evaporated extract the volume reached up to $100 \mathrm{ml}$. then for determination of nitrogen concentration the $65 \mathrm{ml}$ distillate was titrate against $0.005 \mathrm{~N} \mathrm{HCl}$ until pink color appeared and then reading was noted. Blank sample was also run which contain only $20 \mathrm{ml}$ distilled water.

\subsubsection{Plant Phosphorus Concentration}

In a conical flask plant sample of $0.5 \mathrm{~g}$ and $10 \mathrm{ml}$ of nitric acid was taken in conical flask to determine concentration of $\mathrm{P}$ in plants [30]. The flask was then kept for the night to complete the reaction. Then $4 \mathrm{ml}$ perchloric acid was added to it. The flask was then kept on a hot plate for digestion until the color changes and 
white fumes were appeared. The sample was then allowed to cool for some time. The sample was then diluted into $100 \mathrm{ml}$ volumetric flask and the volume was adjusted up to $100 \mathrm{ml}$ by adding distilled water. Then $0.5 \mathrm{ml}$ extract was taken from the solution and transferred it into volumetric flask of $25 \mathrm{ml}$. Ascorbic mix reagent of $5 \mathrm{ml}$ along distilled water of $4 \mathrm{ml}$ was added and up to $25 \mathrm{ml}$ the volume was adjusted by adding distilled water. The flask was then kept in dark for about 15 minutes in order to developed blue color. On spectrophotometer absorption curve was developed for $0,2,4,6,8$, and $10 \mathrm{ppm}$ standard solution for calibration of spectrophotometer. Then extractable phosphorus was determined with the help of spectrophotometer.

\subsubsection{Plant $\mathrm{Fe}, \mathrm{Zn}, \mathrm{Cu}$ and $\mathrm{Mn}$ Concentrations}

Plant sample of $0.5 \mathrm{~g}$ plant sample with $10 \mathrm{ml}$ of nitric acid in a conical flask was taken for determination of micronutrients. The flask was kept for the night to complete the reaction. Then $4 \mathrm{ml}$ perchloric acid was added to it. The flask was then kept on a hot plate for digestion until the color changes and white fumes were appeared. The sample was then allowed to cool for some time. The sample was then diluted into $100 \mathrm{ml}$ volumetric flask and the volume was adjusted up to $100 \mathrm{ml}$ by adding distilled water. The samples were analyzed by the help of atomic absorption spectrophotometer for the determination of $\mathrm{Fe}, \mathrm{Zn}, \mathrm{Cu}$ and Mn.

\subsubsection{Plant Nutrients Uptake}

Nutrients uptake by wheat crop were determined by using the formula.

Plant nutrient concentration $\times$ total dry matter yield.

\section{Results and Discussion}

A field experiment was conducted at the research farm of the University of Agriculture Peshawar, Khyber Pakhtunkhwa, Pakistan to determine the influence of sulphur applied with compost on yield and nutrients uptake of wheat crop.

Physical and chemical properties of soil under investigation are presented in Table 1.

Data in Table 1 showed that soil under study was calcareous in nature, alkaline in reaction. Silt loam in texture, low in OM content, poor in available phosphorus and total nitrogen contents.

\subsection{Compost Analysis}

Concentration of $\mathrm{N}$ and $\mathrm{P}$ in compost under use contains $1.189 \% \mathrm{~N}$ and $0.547 \%$ $\mathrm{P}_{2} \mathrm{O}_{5}$.

\subsubsection{Yield and Yield Components of Wheat}

Yield and yield components of wheat are significantly affected by sulphur applied with compost prepared with FYM and RP is presented in Table 2. 
Table 1. Physico-chemical properties of soil under investigations.

\begin{tabular}{ccc}
\hline Property & Units & Concentration \\
\hline Silt & $\%$ & 64.5 \\
Sand & $\%$ & 29.6 \\
Clay & $\%$ & 5.4 \\
Textural Class & - & Silt loam \\
EC(e) & $\mathrm{dS} \cdot \mathrm{m}^{-1}$ & 0.25 \\
pH & - & 7.81 \\
Organic matter content & $\%$ & 0.76 \\
Lime & $\%$ & 14.7 \\
Soil total N content & $\%$ & 0.12 \\
AB-DTPA extractable P & $\mathrm{mg} \cdot \mathrm{kg}^{-1}$ & 3.26 \\
\hline
\end{tabular}

Table 2. Grain yield, biological yield and Straw yield of wheat as affected by sulphur applied with compost.

\begin{tabular}{|c|c|c|c|}
\hline \multirow{2}{*}{ Treatments } & Grain & Total dry matter & \multirow[t]{2}{*}{ Straw } \\
\hline & \multicolumn{2}{|c|}{ _yield $\left(\mathrm{kg} \cdot \mathrm{ha}^{-1}\right)$} & \\
\hline Control (No fertilizers) & $2463 \mathrm{e}^{*}$ & $6705 f^{*}$ & $4242 c^{*}$ \\
\hline $\mathrm{N}$ and $\mathrm{K}$ fertilizers & $2769 d$ & $7706 \mathrm{e}$ & $4937 \mathrm{~b}$ \\
\hline N, P \& K fertilizers & $3670 b$ & $9085 b$ & $5415 \mathrm{ab}$ \\
\hline Compost & $3198 c$ & $8323 d$ & $5125 \mathrm{ab}$ \\
\hline N, P \& K + S @ $20 \mathrm{~kg} \cdot \mathrm{ha}^{-1}$ & $3688 b$ & $9303 b$ & $5615 a$ \\
\hline Compost + S@10 kg.ha-1 & $3396 b c$ & $8710 c$ & $5313 \mathrm{ab}$ \\
\hline Compost + S@20 kg.ha-1 & $4076 a$ & $9721 \mathrm{a}$ & $5644 a$ \\
\hline Compost + S@30 kg.ha ${ }^{-1}$ & $4037 \mathrm{a}$ & $9645 a$ & $5638 \mathrm{a}$ \\
\hline LSD $P \leq 0.05$ & 299.2 & 341.7 & 531 \\
\hline
\end{tabular}

${ }^{\star}$ Means with different letter $(\mathrm{S})$ in columns are significantly different at $P \leq 0.05$.

\subsubsection{Wheat Grain Yield}

Wheat grain yield as affected by sulphur applied with compost is presented in Table 2. Data revealed that grain yield was significantly affected by treatments combination of sulphur applied with compost. Maximum grain yield of 4076 $\mathrm{kg} \cdot \mathrm{ha} \mathrm{a}^{-1}$ was found with application of compost with S @ $20 \mathrm{~kg} \cdot \mathrm{ha}^{-1}$ with $65 \%$ increase over control (Figure 1). This data were statistically similar with 4037 $\mathrm{kg} \cdot \mathrm{ha}^{-1}$ compost and sulphur at the rate of $30 \mathrm{~kg} \cdot \mathrm{ha}^{-1}$ followed by $\mathrm{N}, \mathrm{P}$ and $\mathrm{K}$ with S, and N, P and K fertilizers. Lowest yield of grains $2463 \mathrm{~kg} \cdot \mathrm{ha}^{-1}$ was recorded in control treatment. [34] investigated that application of sulphur drastically improved wheat yield and yield components. This improvement probably due to creating favorable and healthy environment for plant growth by compost 


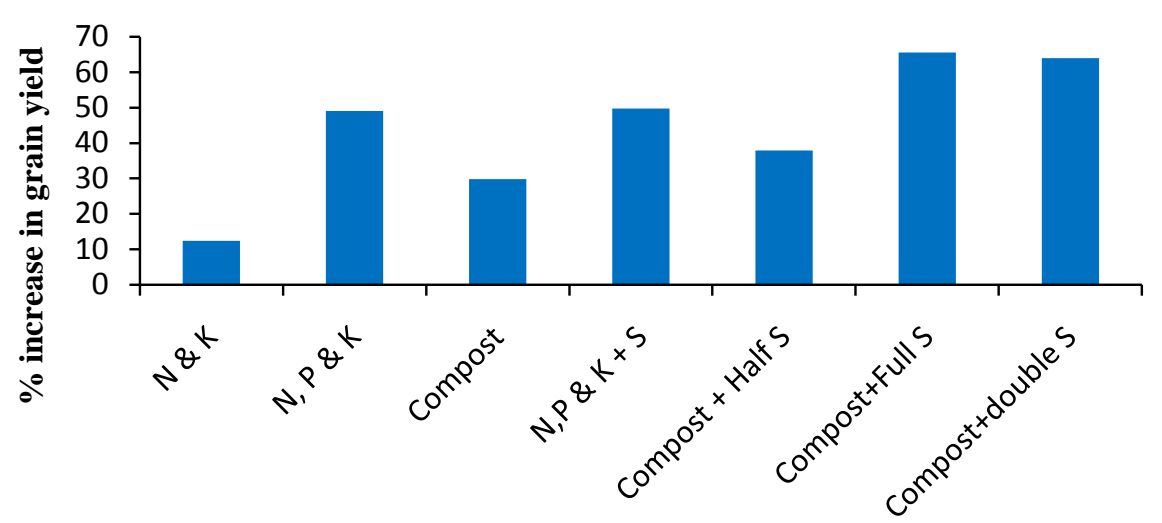

Figure 1. \% increase in grain yield over control as affected by S applied with compost.

applied with [35] [36] and [16] reported similar results. Our results are also similar with [16] and [18] who reported that sulfur use increased wheat grain yield and other cereals. Our results are also similar with [37] and [38] who reported that wheat grain yield considerably increased when RP is mixed with different organic materials. [39] found that maize gain yield was significantly increased by applying RP and organic residues.

\subsubsection{Total Dry Matter Yield}

Data regarding total dry matter yield of wheat as affected by sulphur practical by means of compost prepared with RP are presented in Table 2. Highest dry matter yield of $9721 \mathrm{~kg} \cdot \mathrm{ha}^{-1}$ was observed in the plot treated with compost and S @ $20 \mathrm{~kg} \cdot \mathrm{ha}^{-1}$ which was $44.9 \%$ increase over control (Figure 2) Which was statistically comparable to $4037 \mathrm{~kg} \cdot \mathrm{ha}^{-1}$ produced by compost and S @ $30 \mathrm{~kg} \cdot \mathrm{ha}^{-1}$ followed, by N, P and K with S @ $20 \mathrm{~kg} \cdot \mathrm{ha}^{-1}$ and N, P and K fertilizers. The lowest dry matter yield of $6705 \mathrm{~kg} \cdot \mathrm{ha}^{-1}$ was recorded in the control treatment. These results are in an agreement with of [16] and [18] who noticed that use of sulfur raise biological yield. Our results show similarity with the findings of [40] who concluded that total dry matter yield increases with soil and foliar application of [41] found that RP when applied with organic materials enhanced biological yield of wheat. [42] reported that biological yield improved when RP are applied with different organic materials.

\subsubsection{Wheat Straw Yield}

Table 2 showed mean data of wheat dry straw yield as affected by sulphur applied with compost. Treatment combinations significantly affected straw yield. Highest straw yield of $5644 \mathrm{~kg} \cdot \mathrm{ha}^{-1}$ was produced with compost and $\mathrm{S}$ at the rate of $20 \mathrm{~kg} \cdot \mathrm{ha}^{-1}$ which was $31 \%$ increase over control (Figure 3), and was statistically comparable to 5638 and $5615 \mathrm{~kg} \cdot \mathrm{ha}^{-1}$ compost with S@ $30 \mathrm{~kg} \cdot \mathrm{ha}^{-1}$ and $\mathrm{N}$, $\mathrm{P}, \mathrm{K}$ and $\mathrm{S}$ at the rate of $20 \mathrm{~kg} \cdot \mathrm{ha}^{-1}$. The lower straw yield of $4242 \mathrm{~kg} \cdot \mathrm{ha}^{-1}$ was noticed in the control treatment. This result is resembled by the outcome of [34] who reported that application of sulphur considerably enhanced yield of wheat and yield components. The same results have also been shown by [43] recorded 


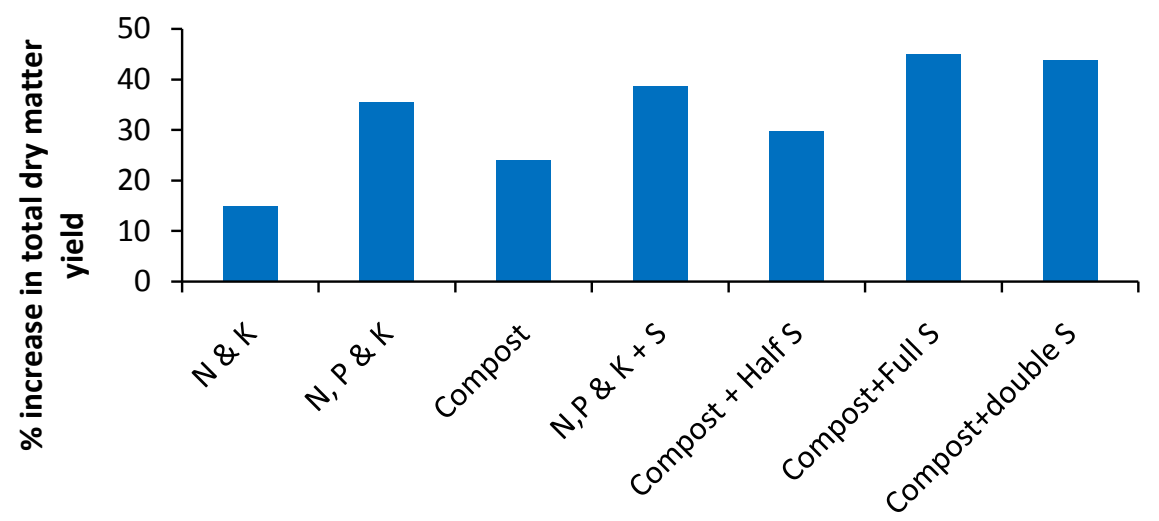

Figure 2. \% increase in total dry matter yield over control as affected by S applied with compost.

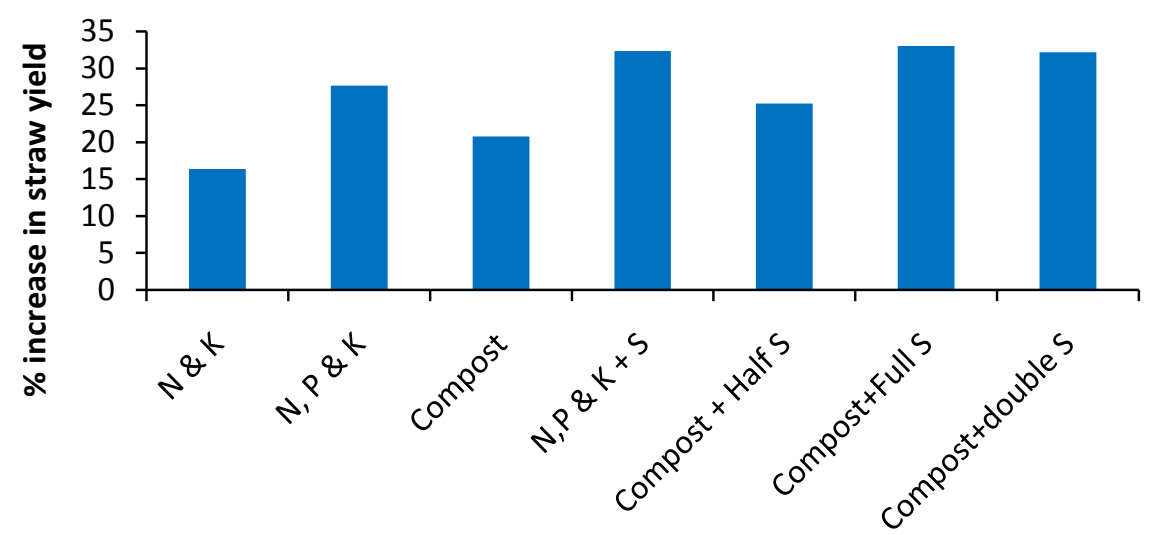

Figure 3. \% increase in straw yield over control as affected by S applied with compost.

that straw yield of wheat enhanced with composts submission organized from different organic materials. The results compiled by [44] showed that by the application of organic and inorganic fertilizers total dry matter yield of crop was drastically increased.

\subsubsection{Plant Height}

Plant height as affected by sulphur applied with compost is shown in Table 3. Data indicated that plant height was significantly affected by sulphur applied with compost. Highest plant height of $98.3 \mathrm{~cm}$ was recorded with compost and $\mathrm{S}$ at the rate of $20 \mathrm{~kg} \cdot \mathrm{ha}^{-1}$ followed by compost and S @ $30 \mathrm{~kg} \cdot \mathrm{ha}{ }^{-1}$. The smallest plant height was recorded in control treatment. These results are also in agreement with [45], in which he noticed that application of S fertilizers drastically affect plant height. [46] supported these results that plant height could be significantly affected with composts enriched with chemical fertilizers.

\subsubsection{Spike Length}

Spike length as affected by sulphur applied with compost is present in Table 3 . Data reveled for plant height is significantly affected by sulphur applied with 
Table 3. Effect of sulphur applied with compost on plants height, spike length, grain per spike and thousand grain weight.

\begin{tabular}{ccccc}
\hline & Plant height & Spike length & $\begin{array}{c}\text { Grain per } \\
\text { spike }\end{array}$ & $\begin{array}{c}\text { Thousand grain } \\
\text { weight }\end{array}$ \\
\cline { 2 - 5 } Treatments & \multicolumn{2}{c}{$(\mathrm{cm})$} & No & $(\mathrm{g})$ \\
\hline Control (No fertilizers) & $78.0 \mathrm{e}^{*}$ & $7.4 \mathrm{e}^{*}$ & $39.3 \mathrm{e}^{*}$ & $33.0 \mathrm{f}^{*}$ \\
N \& K fertilizers & $81.1 \mathrm{~d}$ & $8.4 \mathrm{~d}$ & $43.3 \mathrm{de}$ & $37.9 \mathrm{e}$ \\
N, P \& K fertilizers & $95.7 \mathrm{ab}$ & $10.1 \mathrm{~b}$ & $56.7 \mathrm{~b}$ & $48.3 \mathrm{ab}$ \\
Compost & $87.5 \mathrm{c}$ & $9.0 \mathrm{~cd}$ & $47.4 \mathrm{~d}$ & $40.7 \mathrm{~d}$ \\
N, P \& K + S @ 20 kg.ha ${ }^{-1}$ & $95.8 \mathrm{ab}$ & $10.3 \mathrm{~b}$ & $56.7 \mathrm{~b}$ & $48.6 \mathrm{ab}$ \\
Compost + S @ 10 kg.ha ${ }^{-1}$ & $89.3 \mathrm{c}$ & $9.2 \mathrm{c}$ & $52.3 \mathrm{c}$ & $43.2 \mathrm{c}$ \\
Compost + S @ 20 kg.ha ${ }^{-1}$ & $98.3 \mathrm{a}$ & $11.2 \mathrm{a}$ & $61.0 \mathrm{a}$ & $50.2 \mathrm{a}$ \\
Compost + S @ 30 kg.ha ${ }^{-1}$ & $93.6 \mathrm{~b}$ & $9.9 \mathrm{~b}$ & $54.7 \mathrm{bc}$ & $46.8 \mathrm{~b}$ \\
LSD P $\leq 0.05$ & 3.0 & 0.62 & 4.108 & 2.40 \\
\hline
\end{tabular}

${ }^{*}$ Means with different letter (S) in columns are significantly different at $P \leq 0.05$.

compost. Maximum spike length of $11.2 \mathrm{~cm}$ was recorded in the plot treated with compost with S @ $20 \mathrm{~kg} \cdot \mathrm{ha}^{-1}$ followed by N, P and K with S at the rate 20 $\mathrm{kg} \cdot \mathrm{ha}^{-1}$ and compost with $\mathrm{S}$ at the rate of $30 \mathrm{~kg} \cdot \mathrm{ha}^{-1}$ and $\mathrm{N}, \mathrm{P}$ and $\mathrm{K}$ fertilizers with 10.3, 9.9 and $10.1 \mathrm{~cm}$ respectively. The smallest plant height of $7.4 \mathrm{~cm}$ was recorded in the control treatment. The above values are in lined by means of the outcome of [34] reported that submission of different sullphur fertilizers considerably enhanced yield and yield components of wheat. [35] [36], have also reported comparable results and [16] [47] [48] and [49] that use of organic materials growth of crop may be improved.

\subsubsection{Grain per Spike}

Sulphur applied with compost significantly influenced grain spike ${ }^{-1}$ as shown in Table 3. Maximum grains spike ${ }^{-1} 61$ was observed in the plot treated with compost and $\mathrm{S}$ at the rate of $20 \mathrm{~kg} \cdot \mathrm{ha}^{-1}$ followed by grain spike ${ }^{-1}$ of 56.7 was found with $\mathrm{N}, \mathrm{P}$ and $\mathrm{K}$ with $\mathrm{S}$ at the rate of $20 \mathrm{~kg} \cdot \mathrm{ha}^{-1}$ and N, P and $\mathrm{K}$ fertilizers respectively. Minimum grains spike ${ }^{-1} 39.3$ were observed at control plot which was statistically similar 43.3 of $\mathrm{N}$ and $\mathrm{K}$ at recommended level. These results indicated that grain spike ${ }^{-1}$ was increased with the increasing level of sulphur and compost as shown by [50] who reported that sulphur when applied with HA increased grain per spike and thousand grain weight, because it has the capability of decomposing residues and make nitrogen gradually accessible to soil and plant. [20] and [51] reported that $S$ could increase number of grain per spike. These values resemble to the finding of [52] who investigated that at optimum timings of application of sulphur and nitrogen increased number of grain per spike in wheat. This may be owing to that either foliar spray or through soil application of both sulphur and nitrogen at various growth stages create encouraging environment for tillers and proper nourish- 
ment for crops. [53] reported the same results.

\subsubsection{Thousand Grains Weight}

Thousand grains weight of wheat as affected by sulphur applied with compost is presented in Table 3. Data regarding mean thousand grains weight was significantly affected by the treatment combinations. Maximum thousand grains weight of $50.2 \mathrm{~g}$ was observed with application of compost and $\mathrm{S}$ at the rate of 20 $\mathrm{kg} \cdot \mathrm{ha}^{-1}$ followed by thousand grains weight of $46.8 \mathrm{~g}$ was found with compost and $\mathrm{S}$ at the rate of $30 \mathrm{~kg} \cdot \mathrm{ha}^{-1}$. Minimum thousand grains weight of $33.0 \mathrm{~g}$ was recorded in the control treatment. This may be due to that, competent metabolic behavior which improved moisture and gluten contents of grain and thus increased in weight of grain occurred. [54] showed that thousand grain weight increased with nitrogen and sulphur application. The same results were also presented by [55]. Similar results were also reported by [34] that use of sulphur drastically enhanced wheat yield and its components. These results also support the findings of [56] and [57] who reported that all the growth parameters could be enhanced with compost appliance.

\subsubsection{Soil pH Values}

$\mathrm{pH}$ values noted after crop harvest were non considerably exaggerated by the treatment combination of sulphur applied with compost is shown in Table 4.

The $\mathrm{pH}$ values ranged from 7.75 to 7.46 . These results are in contrast with [58] who stated that make use of sulfur has a major effect in falling soil $\mathrm{pH}$. [59] observed that after five years sulphur intake can diminish soil $\mathrm{pH}$. [60] also accomplished considerable optimistic association with soil $\mathrm{pH}$ due to oxidation of sulfur [30]. [61] found that 0.07-0.35 units decreased in soil $\mathrm{pH}$ was noticed and due to increasing application of sulphur to calcareous soil $\mathrm{pH}$ of the soil was decreased up to the $5^{\text {th }}$ week and after that increased was started in soil $\mathrm{pH}$ [62].

Table 4. Effect of sulphur applied with compost on post harvest soil pH, ECe and SOM contents.

\begin{tabular}{|c|c|c|c|c|}
\hline \multirow{2}{*}{ Treatments } & $\mathrm{pH}$ & $\mathrm{EC}(\mathrm{e})$ & SOM & Lime \\
\hline & $(1: 5)$ & $\left(\mathrm{dS} \cdot \mathrm{m}^{-1}\right)$ & \multicolumn{2}{|c|}{$\ldots(\%)$} \\
\hline Control (No fertilizers) & 7.75 & 0.29 & $0.50 \mathrm{~d}^{*}$ & 17.61 \\
\hline N \& K fertilizers & 7.76 & 0.31 & $0.64 \mathrm{~cd}$ & 18.67 \\
\hline N, P \& K fertilizers & 7.76 & 0.33 & $0.73 \mathrm{c}$ & 17.55 \\
\hline Compost & 7.75 & 0.34 & $1.28 \mathrm{a}$ & 18.45 \\
\hline N, P \& K + S@ $@ 20 \mathrm{~kg} \cdot \mathrm{ha}^{-1}$ & 7.63 & 0.38 & $0.96 \mathrm{~b}$ & 17.63 \\
\hline Compost + S @ $10 \mathrm{~kg} \cdot \mathrm{ha}^{-1}$ & 7.61 & 0.36 & $1.41 \mathrm{a}$ & 18.09 \\
\hline Compost + S @ $20 \mathrm{~kg} \cdot \mathrm{ha}^{-1}$ & 7.54 & 0.38 & $1.28 \mathrm{a}$ & 17.99 \\
\hline Compost + S@ $30 \mathrm{~kg} \cdot \mathrm{ha}^{-1}$ & 7.46 & 0.39 & $1.20 \mathrm{a}$ & 18.36 \\
\hline LSD $P \leq 0.05$ & NS & NS & 0.21 & NS \\
\hline
\end{tabular}

${ }^{\star}$ Means with different letter $(\mathrm{S})$ in columns are significantly different at $P \leq 0.05$. 
reported soil $\mathrm{pH}$ increase with compost consumption.

\subsubsection{Soil Electrical Conductivity}

The soil EC recorded after cop harvest were non significantly affected by sulphur applied with compost as shown in Table 4. It might be due to the reason that total soluble concentrations are statistically similar with each other. The results are in contrast with [63] who reported that EC was significantly affected by the addition of elemental $S$ to calcareous soils. [64] mentioned that soil salinity increased with the constant use of the compost.

\subsubsection{Soil Organic Matter Content}

Analysis of data revealed that soil organic matter content was significantly affected by sulphur applied with compost as presented in Table 5. Highest Soil organic matter content of $1.41 \%, 1.28 \%$ and $1.20 \%$ were observed in the treatment plots of sulphur application with compost, which were statistically similar with each other's. The lowest organic matter content of $0.50 \%$ was noted in the control. It might be due to the reason that incorporation of organic manures enhances SOM content and soil organic carbon. The same results were obtained by [65] who noticed that organic matter content was improved with organic and inorganic fertilizers. [66] supported these results and found that application of rock phosphate through organic manure improved the organic matter content of soil. Our consequences are also supported by the findings of [67] [68] [69] [70] [71]. Comparable outcome were also supported by [72]. Comparable results were also obtained by [73]. Combination of organic fertilizer suggestively increased organic matter [35] and [74].

\subsubsection{Soil Total Nitrogen Content}

Post harvest soil total nitrogen as affected by sulphur applied with compost is given in Table 5 .

Table 5. Post harvest soil $\mathrm{N}$ and $\mathrm{P}$ contents as affected by sulphur applied with compost.

\begin{tabular}{|c|c|c|}
\hline & Total soil $\mathrm{N}$ & AB-DTP A extractable $P$ \\
\hline & \multicolumn{2}{|c|}{ Contents $\left(\mathrm{mg} \cdot \mathrm{kg}^{-1}\right)$} \\
\hline Control (No fertilizers) & $940 d^{*}$ & $3.10 f^{*}$ \\
\hline N \& K fertilizers & $1275 c$ & $3.859 \mathrm{e}$ \\
\hline N, P \& K fertilizers & $1230 \mathrm{c}$ & $4.193 d$ \\
\hline Compost & $1101 \mathrm{~cd}$ & $4.580 c$ \\
\hline N, P \& K + S @ $20 \mathrm{~kg} \cdot \mathrm{ha}^{-1}$ & $1111 \mathrm{~cd}$ & $5.168 \mathrm{~b}$ \\
\hline Compost + S @ $10 \mathrm{~kg} \cdot \mathrm{ha}^{-1}$ & $1477 b$ & $4.925 b$ \\
\hline Compost + S @20 kg.ha ${ }^{-1}$ & $1613 \mathrm{ab}$ & $5.567 \mathrm{a}$ \\
\hline Compost + S @ $30 \mathrm{~kg} \cdot \mathrm{ha}^{-1}$ & $1756 a$ & $5.704 a$ \\
\hline LSD $P \leq 0.05$ & 194.56 & 0.321 \\
\hline
\end{tabular}

${ }^{\star}$ Means with different letter (S) in columns are significantly different at $P \leq 0.05$. 
Analysis of data indicated that soil total nitrogen content was considerably affected by sulphur applied with compost. Highest total soil N of $1756 \mathrm{mg} \cdot \mathrm{kg} \cdot \mathrm{ha}^{-1}$ was observed with submission of compost and $\mathrm{S}$ at the rate of $30 \mathrm{~kg} \cdot \mathrm{ha}^{-1} \mathrm{fol}-$ lowed by compost with S @ $10 \mathrm{~kg} \cdot \mathrm{ha}^{-1}$. The lowest total soil nitrogen of 940 $\mathrm{mg} \cdot \mathrm{kg}^{-1}$ was noted in the control treatment. [41] reported the same results, who observed increased concentration in total soil nitrogen through application of organic materials with rock phosphate. Similar results have been shown by [16] who stated that the relevance of rock phosphate with organic manure have the capability to the soil nitrogen and phosphorus concentration and plant uptake. The same results were also presented by [75] found that maize yield and soil nitrogen were significantly increased when organic manure was applied in combination with NPK. These fallout are in line with [76], reported that after composting process the raise might be credited to a straight result of organic nitrogen resulting from the compost, which is gradually mineralized in soil [77]. Our results are also supported by [78].

\subsubsection{Post Harvest Soil P Content}

Analysis of data revealed that post harvest soil $\mathrm{P}$ content was considerably affected by treatment combination of sulphur applied with compost is present in Table 5. Highest soil P content of $5.704 \mathrm{mg} \cdot \mathrm{kg} \cdot \mathrm{ha}^{-1}$ was obtained by means of compost and S @ $30 \mathrm{~kg} \cdot \mathrm{ha}^{-1}$, which was statically similar to compost and S @ 20 $\mathrm{kg} \cdot \mathrm{ha}^{-1}$ followed by N, P and K with S @ $20 \mathrm{~kg} \cdot \mathrm{ha}^{-1}$, which was similar to compost and $\mathrm{S}$ at the rate of $10 \mathrm{~kg} \cdot \mathrm{ha}^{-1}$. The lowest soil $\mathrm{P}$ content of $3.10 \mathrm{mg} \cdot \mathrm{kg}^{-1}$ was recorded in the control treatment. The comparable results was obtained by [14] who found that it may be due to that sulphur reduced $\mathrm{pH}$ of the soil and making phosphorus and micronutrients more available. Similarly [79] and [80] and [81] found that sulphur has helpful outcome from the soil on releasing phosphorus and increased the yield of plant. Comparable results were also reported by [41] who found that concentration of $\mathrm{P}$ might be amplified when organic materials are mixed with rock phosphate. Comparable results were also reported by [48] and [67] who noticed that use of inorganic and organic manures increased the phosphorus availability in the soil. Over results are also supported by [71] [82] [83] [84].

\subsubsection{Plant Nitrogen and Phosphorus Concentration}

Data regarding plant $\mathrm{N}$ and $\mathrm{P}$ concentration as affected by sulphur applied with compost are presented in present in Table 6.

\subsubsection{Plant N Concentration}

Data regarding plant $\mathrm{N}$ concentration as affected by sulphur applied with compost are presented in Table 6 .

Data regarding plant $\mathrm{N}$ concentration as significantly affected by the submission of sulphur applied with compost. Maximum plant $\mathrm{N}$ concentration of $1.29 \%$ was obtained with appliance of compost with S @ $20 \mathrm{~kg} \cdot \mathrm{ha}^{-1}$ followed by compost and S@30 kg.ha ${ }^{-1}$. The lowest plant $\mathrm{N}$ concentration of $0.85 \%$ was 
Table 6. Plant nitrogen and phosphorus concentration of wheat as affected by sulphur applied with compost.

\begin{tabular}{|c|c|c|}
\hline \multirow{2}{*}{ Treatments } & Plant N & Plant P \\
\hline & \multicolumn{2}{|c|}{ _Concentration (\%) } \\
\hline Control (No fertilizers) & $0.85 \mathrm{~d}^{*}$ & $0.07 \mathrm{~d}^{*}$ \\
\hline $\mathrm{N} \& \mathrm{~K}$ fertilizers & $1.22 \mathrm{~b}$ & $0.10 c$ \\
\hline N, P \& K fertilizers & $1.12 \mathrm{c}$ & $0.14 \mathrm{~b}$ \\
\hline Compost & $1.25 \mathrm{ab}$ & $0.13 b c$ \\
\hline N, P \& K + S @ $20 \mathrm{~kg} \cdot \mathrm{ha}^{-1}$ & $1.13 \mathrm{c}$ & $0.14 \mathrm{~b}$ \\
\hline Compost + S @ $10 \mathrm{~kg} \cdot \mathrm{ha}^{-1}$ & $1.23 \mathrm{~b}$ & $0.15 \mathrm{ab}$ \\
\hline Compost + S@ $@ 20 \mathrm{~kg} \cdot \mathrm{ha}^{-1}$ & $1.29 \mathrm{a}$ & $0.18 \mathrm{a}$ \\
\hline Compost + S@ $@ 30 \mathrm{~kg} \cdot \mathrm{ha}^{-1}$ & $1.27 \mathrm{ab}$ & $0.17 \mathrm{a}$ \\
\hline LSD $P \leq 0.05$ & 0.06 & 0.03 \\
\hline
\end{tabular}

${ }^{*}$ Means with different letter (S) in columns are significantly different at $P \leq 0.05$.

observed in the control treatment. This result is an agreement with [85] who observed that concentration of nitrogen in plant can be enhanced by the use of rock phosphate assorted with organic materials. [86] also supported our results that plant $\mathrm{N}$ concentration is able to raise by the combined submission of organic and inorganic sources of N. Further scientists [47] [48] and [67] in various plants also practical amplified concentration of nitrogen, phosphorus and potassium when organic and inorganic fertilizers were applied from different sources such as FYM, green manure and chemical fertilizers. Our results are also supported by [87].

\subsubsection{Plant $P$ Concentration}

Wheat plant $\mathrm{P}$ concentration as affected by sulphur applied with compost is shown in Table 6. Plant $\mathrm{P}$ concentration was drastically affected by sulphur applied with compost. Highest plant P concentration of $0.24 \%$ was recorded with submission of compost and S @ $20 \mathrm{~kg} \cdot \mathrm{ha}^{-1}$, which was statistically comparable to compost and $\mathrm{S}$ at the rate of $30 \mathrm{~kg} \cdot \mathrm{ha}^{-1}$, followed by N, P and K with S@ 20 $\mathrm{kg} \cdot \mathrm{ha}^{-1}$. The lowest plant $\mathrm{P}$ concentration of $0.08 \%$ was observed in the control treatment. This might be due to that around the roots in small areas $\mathrm{pH}$ of the calcareous soil decreased by the addition of sulphur and absorption potential of phosphorus increases [88]. Composts prepared with rock phosphate out additional amounts of alkaline phosphates and acid in soil as compared to other common composts, improved phosphorus solubilization for longer time. During nitrogen fixation, legumes may be able to release supplementary phosphorus from RP by means of rhizosphere acidification [9]. [47] [48] [67] also observed better uptake of nitrogen, phosphorus and potassium concentration by plant were ominously inclined by organic manures. [71] [82] [87] and [89] founded that addition of naturals manures and compost to soil improved the Nitrogen, 
Phosphorus and potassium concentrations in plant.

\subsubsection{Plant N Uptake}

Wheat plant $\mathrm{N}$ uptake as affected by sulphur applied with compost is shown in Table 7 .

Analysis of data shows that plant $\mathrm{N}$ uptake was significantly affected by sulphur applied with compost. Highest $\mathrm{N}$ uptake of $125.7 \mathrm{~kg} \cdot \mathrm{ha}^{-1}$ was recorded by the use of compost and S @ $20 \mathrm{~kg} \cdot \mathrm{ha}^{-1}$ which was $141 \%$ increase over control (Figure 4) and was statistically similar to compost with S@ $30 \mathrm{~kg} \cdot \mathrm{ha}^{-1}$ followed by $\mathrm{N}, \mathrm{P}$ and $\mathrm{K}$ with $\mathrm{S}$ at the rate of $10 \mathrm{~kg} \cdot \mathrm{ha}^{-1}$. The lowest plant nitrogen uptake of $51 \mathrm{~kg} \cdot \mathrm{ha}^{-1}$ was recorded in the control treatment. These results are conformity with [85] who observed that RP when assorted with organic materials can develop nitrogen uptake by plant. [86] also support our results that uptake of nitrogen by plant can be increased by the combined use of organic and inorganic sources of N. Further researchers [47] [48] [67] also observed improved uptake of nitrogen, phosphorus and potassium when organic and inorganic fertilizers were applied from different sources. Our results are also supported by [87] originate that plant nitrogen and phosphorus uptake were increased when rock phosphate was mixed organic fertilizers.

\subsubsection{Plant P Uptake}

Plant P uptake was significantly affected by sulphur applied with compost is shown in Table 7. The highest plant $P$ uptakes of $17.5 \mathrm{~kg} \cdot \mathrm{ha}^{-1}$ was recorded with the application of compost and $\mathrm{S}$ at the rate of $20 \mathrm{~kg} \cdot \mathrm{ha}^{-1}$, which was $272.3 \%$, increase over control (Figure 5) and was statically similar to compost with $S$ at the rate of $30 \mathrm{~kg} \cdot \mathrm{ha}^{-1}$. The lowest plant $\mathrm{P}$ uptake of $4.3 \mathrm{~kg}^{-1}$ was noted in the control treatment. This may be due to that sulphur reduced $\mathrm{pH}$ of the soil and making phosphorus and micronutrients more available to the plant [79]. Our results were also supported by [90] who experiential that uptake of phosphorus by plant

Table 7. Plant $\mathrm{N}$ and $\mathrm{P}$ uptake of wheat as influenced by sulphur applied with compost.

\begin{tabular}{|c|c|c|}
\hline \multirow{2}{*}{ Treatments } & $\mathbf{N}$ & $\mathbf{P}$ \\
\hline & \multicolumn{2}{|c|}{ Plant uptake $\left(\mathrm{kg} \cdot \mathrm{ha}^{-1}\right)$} \\
\hline Control ( No fertilizers ) & $57.0 c^{*}$ & $4.7 c^{*}$ \\
\hline N \& K fertilizers & $94.2 \mathrm{~d}$ & $7.9 \mathrm{~d}$ \\
\hline N, P \& K fertilizers & $101.5 \mathrm{~b}$ & $12.7 \mathrm{~b}$ \\
\hline Compost & $103.7 b$ & $11.1 \mathrm{~b}$ \\
\hline N, P \& K + S @ 20 kg.ha ${ }^{-1}$ & $105.1 \mathrm{~b}$ & $13.0 \mathrm{~b}$ \\
\hline Compost + S @10 kg.ha ${ }^{-1}$ & $106.8 \mathrm{~b}$ & $13.4 \mathrm{~b}$ \\
\hline Compost + S @ $20 \mathrm{~kg} \cdot \mathrm{ha}^{-1}$ & $125.7 \mathrm{a}$ & $17.5 \mathrm{a}$ \\
\hline Compost + S @ $30 \mathrm{~kg} \cdot \mathrm{ha}^{-1}$ & $122.9 \mathrm{a}$ & $16.7 \mathrm{a}$ \\
\hline LSD $P \leq 0.05$ & 6.73 & 2.73 \\
\hline
\end{tabular}

${ }^{*}$ Means with different letter $(\mathrm{S})$ in columns are significantly different at $P \leq 0.05$. 


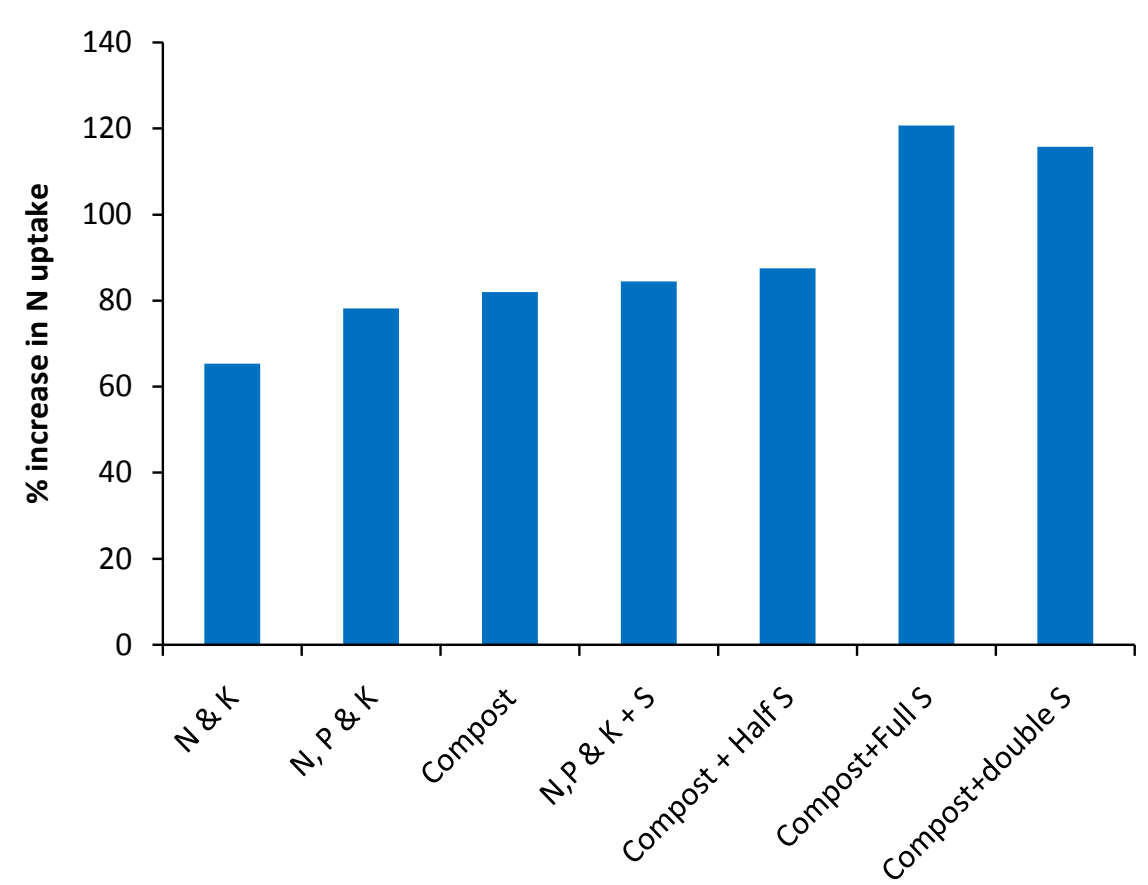

Figure 4. \% increase in uptake of $\mathrm{N}$ over control as affected by $\mathrm{S}$ applied with compost.

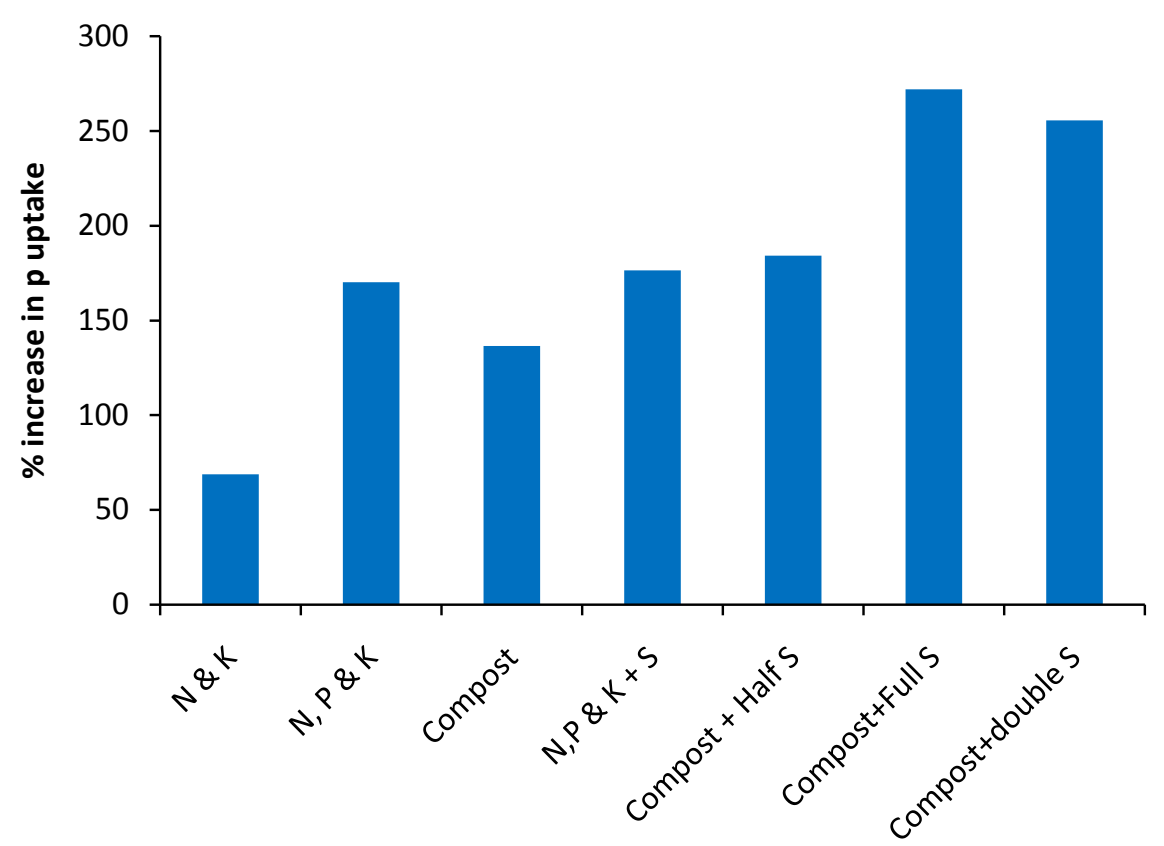

Figure 5. \% increase in uptake of $\mathrm{P}$ over control as affected by $\mathrm{S}$ applied with compost

were significantly increased with residual effect of N-based compost. [87] also found that plant nitrogen and phosphorus uptakes were improved when RP was applied was mixed with organic fertilizers. [47] [48] [67] also observed N, P and $\mathrm{K}$ increased uptake by plant were ominously inclined by organic manures. [71] [82] [87] and [89] founded that addition of naturals manures and compost to soil improved the Nitrogen, Phosphorus and potassium concentrations in plant. 


\subsubsection{Plant Fe Concentration}

Table 8 showed the mean data of plant micronutrients concentration as affected by sulphur applied with compost.

Table 8 showed the mean data of plant micronutrients concentration as affected by sulphur applied with compost. Results showed that Fe concentration in plant was significantly affected by sulphur applied with compost. Maximum plant Fe concentration of $58.1 \mathrm{mg} \cdot \mathrm{kg}^{-1}$ was recorded with application of compost and S @ $20 \mathrm{~kg} \cdot \mathrm{ha}^{-1}$, which was statistically similar to N, P, K with S @ $20 \mathrm{~kg} \cdot \mathrm{ha}^{-1}$ and $\mathrm{N}, \mathrm{P}$ and $\mathrm{K}$ followed by compost and S @ $30 \mathrm{~kg} \cdot \mathrm{ha}^{-1}$. The lowest plant Fe concentration of $38.2 \mathrm{mg} \cdot \mathrm{kg}^{-1}$ was observed in the control treatment. The same results was obtained by [79] who found that it may be due to that sulphur reduced $\mathrm{pH}$ of the soil and making phosphorus and micronutrients more available to the plant. Our results were also supported by [80] who reported that utilization of sulfur in calcareous soil and with neutralizing lime improved accessibility of iron. [79] showed the same results.

\subsubsection{Plant Zn Concentration}

Table 8 showed the mean data of plant micronutrients concentration as affected by sulphur applied with compost. Results show that $\mathrm{Zn}$ concentration in plant was significantly affected by sulphur applied with compost. Maximum plant $\mathrm{Zn}$ concentration of $42.03 \mathrm{mg} \cdot \mathrm{kg}^{-1}$ was recorded with application of compost and S at the rate of $20 \mathrm{~kg} \cdot \mathrm{ha}^{-1}$, Which was statistically similar to N, P, K and S@ 20 $\mathrm{kg} \cdot \mathrm{ha}^{-1}$ and compost with $\mathrm{S}$ at the rate of $20 \mathrm{~kg} \cdot \mathrm{ha}^{-1}$ and $\mathrm{N}, \mathrm{P}$ and $\mathrm{K}$ followed by compost and S@10 kg.ha ${ }^{-1}$. The lowest plant zinc concentration of 25.07 $\mathrm{mg} \cdot \mathrm{kg}^{-1}$ was observed in the control treatment. [91] supported our results who reported that use of elemental sulphur improved zinc and cadmium solubilization in soil and amplified their uptake by plants. [92] reported that $\mathrm{Fe}, \mathrm{Zn}$ and $\mathrm{Cu}$ concentration by plant were ominously inclined by compost. [93] reported

Table 8. Plant micronutrients concentration as affected by sulphur applied with compost.

\begin{tabular}{|c|c|c|c|c|}
\hline \multirow{2}{*}{ Treatments } & $\mathrm{Fe}$ & $\mathrm{Zn}$ & $\mathrm{Cu}$ & $\mathrm{Mn}$ \\
\hline & \multicolumn{4}{|c|}{$\mathrm{mg} \cdot \mathrm{kg}^{-1}$} \\
\hline Control (No fertilizers) & $38.2 \mathrm{e}^{\star}$ & $25.07 \mathrm{~d}^{*}$ & $6.0 \mathrm{e}^{\star}$ & $65.8 \mathrm{e}^{*}$ \\
\hline N \& K fertilizers & $42.5 \mathrm{~d}$ & $28.30 c$ & $8.4 \mathrm{~d}$ & $72.5 \mathrm{~d}$ \\
\hline N, P \& K fertilizers & $57.3 \mathrm{a}$ & $40.57 \mathrm{a}$ & $10.4 \mathrm{c}$ & $93.7 \mathrm{a}$ \\
\hline Compost & $47.0 \mathrm{c}$ & $34.13 b$ & $12.0 \mathrm{bc}$ & $79.2 c$ \\
\hline N, P \& K + S@ $@ 20 \mathrm{~kg} \cdot \mathrm{ha}^{-1}$ & $57.3 \mathrm{a}$ & $40.87 a$ & $10.6 c$ & $94.6 \mathrm{a}$ \\
\hline Compost+S@10 kg.ha ${ }^{-1}$ & $51.1 b c$ & $35.73 b$ & $13.1 \mathrm{~b}$ & $86.6 b$ \\
\hline Compost+S@20 kg.ha ${ }^{-1}$ & $58.1 \mathrm{a}$ & $42.03 \mathrm{a}$ & $16.3 \mathrm{a}$ & $95.5 \mathrm{a}$ \\
\hline Compost + S @ $30 \mathrm{~kg} \cdot \mathrm{ha}^{-1}$ & $52.7 \mathrm{~b}$ & $39.03 \mathrm{a}$ & $15.3 \mathrm{a}$ & $90.2 \mathrm{ab}$ \\
\hline LSD $P \leq 0.05$ & 4.05 & 3.043 & 1.80 & 6.16 \\
\hline
\end{tabular}

${ }^{\star}$ Means with different letter $(\mathrm{S})$ in columns are significantly different at $P \leq 0.05$. 
that using organic fertilizers the organic matter of the soil increases and thus increases the concentration of $\mathrm{Fe}, \mathrm{Zn}, \mathrm{Cu}, \mathrm{Mn}, \mathrm{N}, \mathrm{P}$, and $\mathrm{K}$ in plant.

\subsubsection{Plant $\mathrm{Cu}$ Concentration}

Concentration of $\mathrm{Cu}$ in wheat plant as affected by sulphur applied with compost is presented in Table 8. Data show that $\mathrm{Cu}$ concentration was significantly affected by treatment combination of sulphur applied with compost. Highest plant $\mathrm{Cu}$ concentration of $16.3 \mathrm{mg} \cdot \mathrm{kg}^{-1}$ was observed with submission of compost and S @ $20 \mathrm{~kg} \cdot \mathrm{ha}^{-1}$ which was statistically similar to compost with S@ $30 \mathrm{~kg} \cdot \mathrm{ha}^{-1}$ followed, by compost and S @ $10 \mathrm{~kg} \cdot \mathrm{ha}^{-1}$. Lowest plant $\mathrm{Cu}$ concentration of 6.0 $\mathrm{mg} \cdot \mathrm{kg}^{-1}$ was noted in the control treatment. [93] reported that using organic fertilizers the organic matter of the soil increases and thus increases the concentration of $\mathrm{Fe}, \mathrm{Zn}, \mathrm{Cu}, \mathrm{Mn}, \mathrm{N}, \mathrm{P}$, and $\mathrm{K}$ in plant. [91] [94] [95] founded that $\mathrm{pH}$ reducing agents such as sulphur and sulphuric acid improves the properties of calcareous soils and enhanced the concentration of nutrients, including micronutrients.

\subsubsection{Plant Mn Concentration}

Concentration of $\mathrm{Mn}$ in wheat plant as affected by sulphur applied with compost is given in Table 8. Data show that Mn concentration was significantly affected by treatment combination of sulphur applied with compost. Highest plant $\mathrm{Mn}$ concentration of $95.5 \mathrm{mg} \cdot \mathrm{kg}^{-1}$ was noticed by submission of compost and $\mathrm{S}$ at the rate of $20 \mathrm{~kg} \cdot \mathrm{ha}^{-1}$ that was statistically comparable to $\mathrm{N}, \mathrm{P}$ and $\mathrm{K}$ fertilizers followed by compost and S@10 kg.ha ${ }^{-1}$. Lowest plant Mn concentration of 65.8 $\mathrm{mg} \cdot \mathrm{kg}^{-1}$ was observed in the control treatment. Our results are comparable with the result of [91] [94] [95] founded that $\mathrm{pH}$ reducing agents such as sulphur and sulphuric acid improves the properties of calcareous soils and enhanced the concentration of nutrients, including micronutrients. [93] reported that using organic fertilizers the organic matter of the soil increases and thus increases the concentration of $\mathrm{Fe}, \mathrm{Zn}, \mathrm{Cu}, \mathrm{Mn}, \mathrm{N}, \mathrm{P}$, and $\mathrm{K}$ in plant.

\subsubsection{Plant Fe Uptake}

Wheat plant Fe uptake as affected by sulphur applied with compost is present in Table 9. Data show that plant Fe uptake was significantly affected by treatment combination. Highest plant Fe uptake of $0.56 \mathrm{~kg} \cdot \mathrm{ha}^{-1}$ was recorded with application of compost and S @ $20 \mathrm{~kg} \cdot \mathrm{ha}^{-1}$ which was $124 \%$ increase over control (Figure 6), Followed by N, P and K with S @ $20 \mathrm{~kg} \cdot \mathrm{ha}^{-1}$. The lowest plant Fe uptake of $0.25 \mathrm{~kg} \cdot \mathrm{ha}^{-1}$ was recorded in the control treatment. This result was is in agreement with [79] who found that it may be due to that sulphur reduced $\mathrm{pH}$ of the soil and making phosphorus and micronutrients more available to the plant. [93], reported that using organic fertilizers the organic matter of the soil increases and thus increases the concentration of $\mathrm{Fe}, \mathrm{Zn}, \mathrm{Cu}, \mathrm{Mn}, \mathrm{N}, \mathrm{P}$, and $\mathrm{K}$ in plant. Our results were supported by [79] who reported that concentration of iron was increased in silage corn by with application of S. Similarly [96] supported our results in their findings that $\mathrm{Fe}$ and $\mathrm{Zn}$ uptake was increased in 
Table 9. Plant micronutrients uptake as affected by sulphur applied with compost.

\begin{tabular}{|c|c|c|c|c|}
\hline \multirow{2}{*}{ Treatments } & $\mathrm{Fe}$ & $\mathrm{Zn}$ & $\mathrm{Cu}$ & Mn \\
\hline & \multicolumn{4}{|c|}{ Plants uptake $\left(\mathrm{kg} \cdot \mathrm{ha}^{-1}\right)$} \\
\hline Control (No fertilizers) & $0.26 \mathrm{~g}^{*}$ & $0.17 f^{*}$ & $0.04 \mathrm{f}^{*}$ & $0.44 \mathrm{~d}^{x}$ \\
\hline N \& K fertilizers & $0.33 \mathrm{f}$ & $0.22 \mathrm{e}$ & $0.06 \mathrm{e}$ & $0.56 \mathrm{c}$ \\
\hline N, P \& K fertilizers & $0.53 b$ & $0.38 \mathrm{~b}$ & $0.10 \mathrm{~b}$ & $0.88 \mathrm{~b}$ \\
\hline Compost & $0.39 \mathrm{e}$ & $0.28 \mathrm{~d}$ & $0.10 \mathrm{~d}$ & $0.66 \mathrm{~b}$ \\
\hline N, P \& K + S @ $20 \mathrm{~kg} \cdot \mathrm{ha}^{-1}$ & $0.53 b$ & $0.38 \mathrm{~b}$ & $0.10 \mathrm{~b}$ & $0.88 \mathrm{~b}$ \\
\hline Compost + S @ $10 \mathrm{~kg} \cdot \mathrm{ha}^{-1}$ & $0.44 \mathrm{~d}$ & $0.31 \mathrm{c}$ & $0.11 \mathrm{c}$ & $0.75 b$ \\
\hline Compost + S @ $20 \mathrm{~kg} \cdot \mathrm{ha}^{-1}$ & $0.56 \mathrm{a}$ & $0.41 \mathrm{a}$ & $0.16 \mathrm{a}$ & $0.93 \mathrm{a}$ \\
\hline Compost + S @ $30 \mathrm{~kg} \cdot \mathrm{ha}^{-1}$ & $0.50 \mathrm{c}$ & $0.38 \mathrm{~b}$ & $0.15 b$ & $0.87 \mathrm{a}$ \\
\hline LSD $P \leq 0.05$ & 0.03 & 0.02 & 0.02 & 0.04 \\
\hline
\end{tabular}

${ }^{*}$ Means with different letter (S) in columns are significantly different at $P \leq 0.05$.

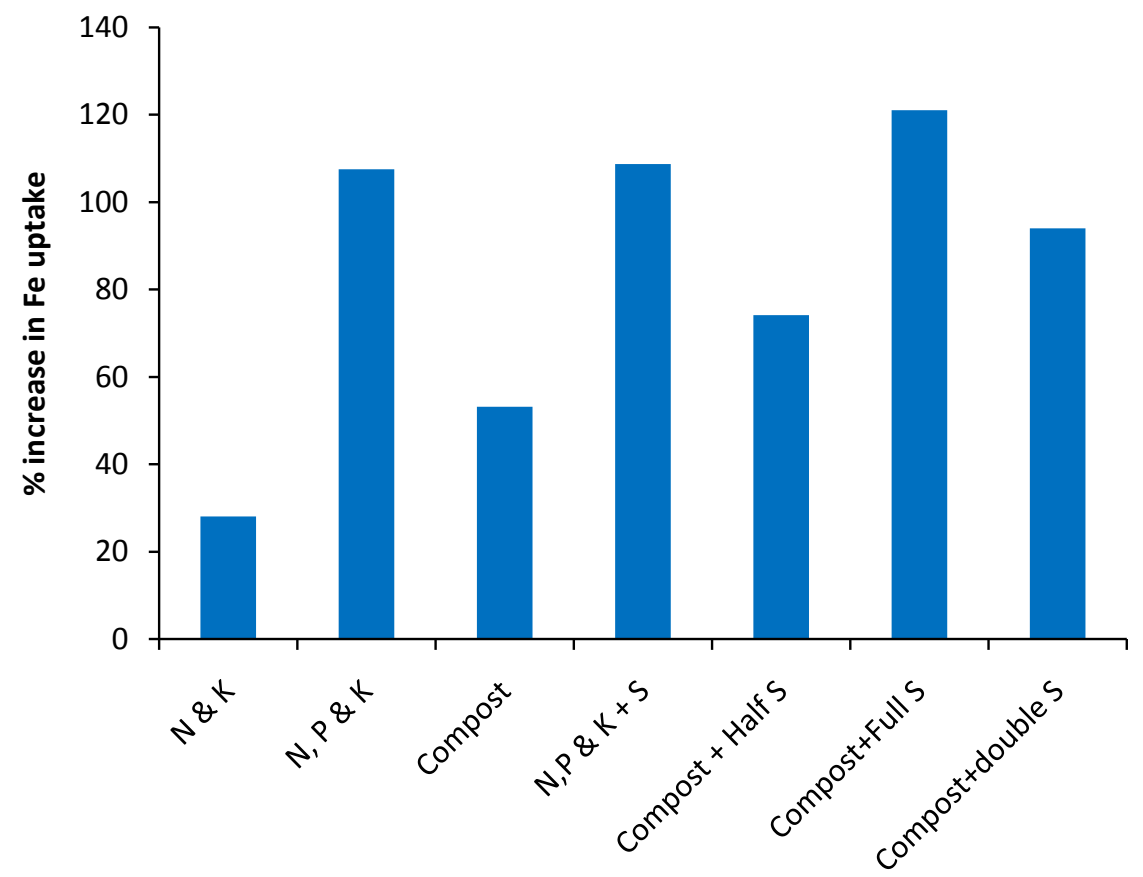

Figure 6. \% increase in plant uptake of Fe over control as affected by S applied with compost.

calcareous soils by sulphur application.

\subsubsection{Plant Zn Uptake}

Wheat plant $\mathrm{Zn}$ uptake as affected by sulphur applied with compost is shown in Table 9. Data show that plant $\mathrm{Zn}$ uptake was significantly affected by treatment combination. Highest plant $\mathrm{Zn}$ uptake of $0.41 \mathrm{~kg} \cdot \mathrm{ha}^{-1}$ was recorded with application of compost and $\mathrm{S}$ at the rate of $20 \mathrm{~kg} \cdot \mathrm{ha} \mathrm{a}^{-1}$, which was $143 \%$ increase over control (Figure 7) followed by N, P and K and S @ $20 \mathrm{~kg} \cdot \mathrm{ha}^{-1}$ and compost with 


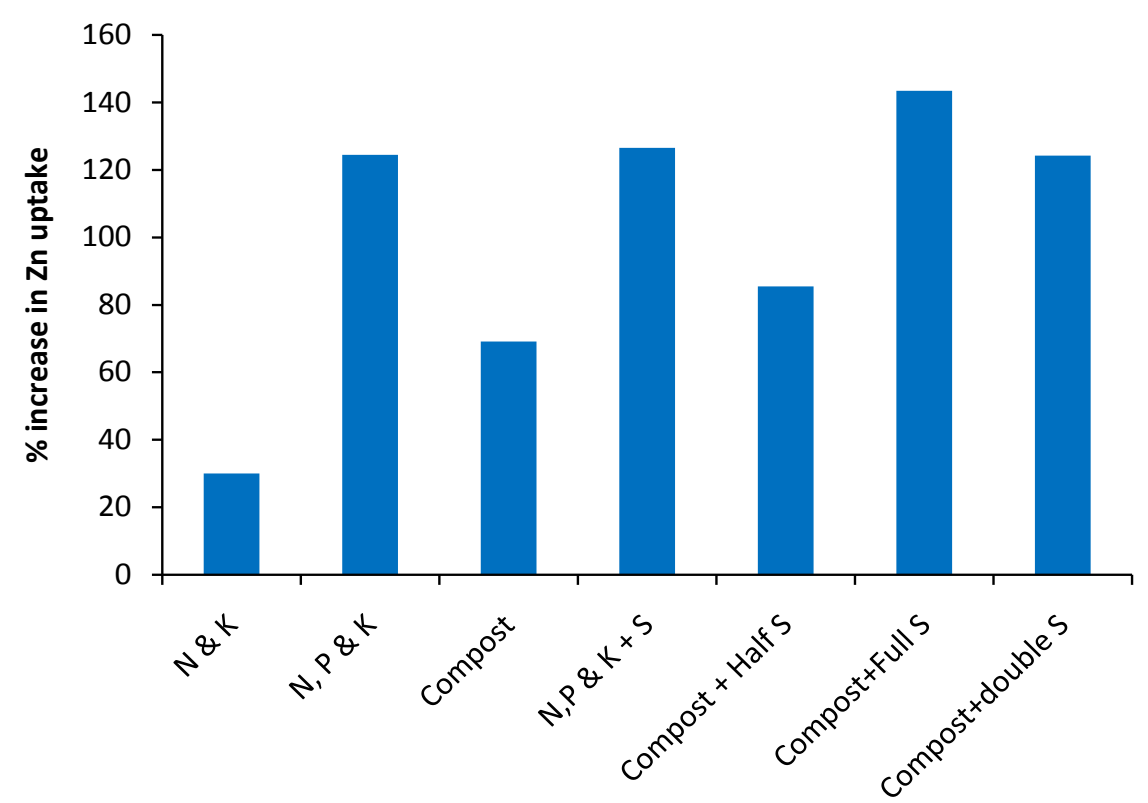

Figure 7. \% increase in plant uptake of $\mathrm{Zn}$ over control as affected by S applied with compost.

$\mathrm{S}$ at the rate of $30 \mathrm{~kg} \cdot \mathrm{ha}^{-1}$. The lowest plant $\mathrm{Zn}$ uptake of $0.17 \mathrm{~kg} \cdot \mathrm{ha}^{-1}$ was recorded in the control treatment. [93], reported that using organic fertilizers the organic matter of the soil increases and thus increases the concentration of Fe, $\mathrm{Zn}, \mathrm{Cu}, \mathrm{Mn}, \mathrm{N}, \mathrm{P}$, and $\mathrm{K}$ in plant. Similarly [96] supported our results in their findings that $\mathrm{Fe}$ and $\mathrm{Zn}$ uptake was increased in calcareous soils by sulphur application.

\subsubsection{Plant Cu Uptake}

Table 9 showed mean data of $\mathrm{Cu}$ uptake by wheat as influenced by sulphur applied with compost. Plant $\mathrm{Cu}$ uptake was significantly affected by treatment combinations of sulphur applied with compost. Highest plant $\mathrm{Cu}$ uptake of 0.16 $\mathrm{kg} \cdot \mathrm{ha}^{-1}$ was noted with application of compost and S @ $20 \mathrm{~kg} \cdot \mathrm{ha}^{-1}$, which was $300 \%$ increase over control (Figure 8), followed by compost with S @ $30 \mathrm{~kg} \cdot \mathrm{ha}^{-1}$ and $\mathrm{N}, \mathrm{P}$ and $\mathrm{K}$ fertilizers. Lowest plant $\mathrm{Cu}$ uptake of $0.04 \mathrm{~kg} \cdot \mathrm{ha}^{-1}$ was practical in the control treatment. [93] reported that using organic fertilizers the organic matter of the soil increases and thus increases the concentration of $\mathrm{Fe}, \mathrm{Zn}, \mathrm{Cu}$, $\mathrm{Mn}, \mathrm{N}, \mathrm{P}$, and $\mathrm{K}$ in plant. [92] reported that $\mathrm{Fe}, \mathrm{Zn}$ and $\mathrm{Cu}$ concentration by plant were ominously inclined by compost.

\subsubsection{Plant Mn Uptake}

Table 9 showed mean data of Mn uptake by wheat plant as influenced by sulphur applied with compost. Plant Mn uptake was significantly affected by treatment combinations of sulphur applied with compost. Highest plant Mn uptake of $0.93 \mathrm{~kg} \cdot \mathrm{ha}^{-1}$ was noted with application of compost and S @ $20 \mathrm{~kg} \cdot \mathrm{ha}^{-1}$, which was $111 \%$ increase over control (Figure 9), followed by N, P and K with S @ 20 $\mathrm{kg} \cdot \mathrm{ha}^{-1}$ and was statistically similar with compost with $\mathrm{S} @ 10 \mathrm{~kg} \cdot \mathrm{ha}^{-1}$. Lowest 


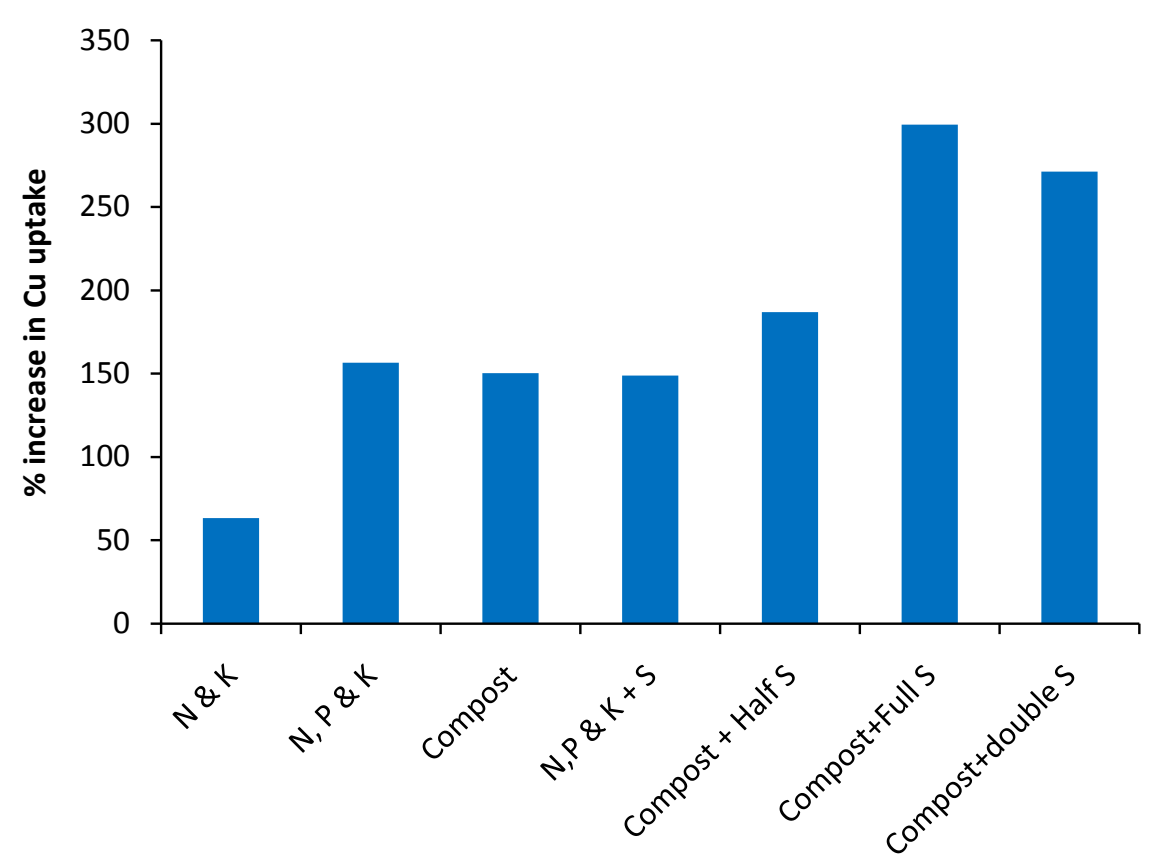

Figure 8. \% increase in plant uptake of $\mathrm{Cu}$ over control as affected by $\mathrm{S}$ applied with compost.

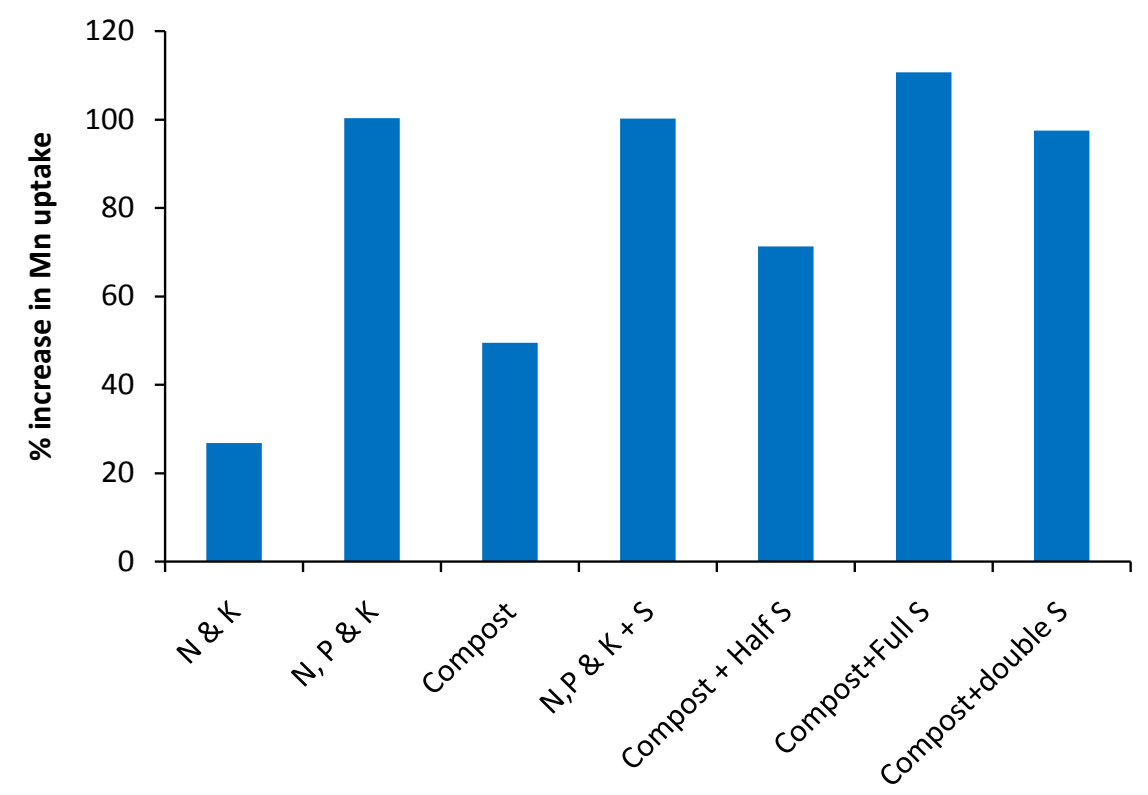

Figure 9. \% increase in plant uptake of Mn over control as affected by S applied with compost.

plant Mn of $0.44 \mathrm{~kg} \cdot \mathrm{ha}^{-1}$ was observed in the control treatment. [93] reported that using organic fertilizers the organic matter of the soil increases and thus increases the concentration of, $\mathrm{Zn}, \mathrm{Cu}, \mathrm{Fe}, \mathrm{Mn}, \mathrm{N}, \mathrm{P}$, and $\mathrm{K}$ in plant. [91] [94] [95] founded that $\mathrm{pH}$ reducing agents such as sulphur and sulphuric acid improves the properties of calcareous soils and enhanced the concentration of nutrients, including micronutrients. 


\section{Conclusions}

Following conclusions are drawn from the results of the conducted research work.

Sulphur application with compost prepared from farm yard manure and rock phosphate significantly increased grain $\left(4076 \mathrm{~kg} \cdot \mathrm{ha}^{-1}\right)$, total dry matter yield $\left(9721 \mathrm{~kg} \cdot \mathrm{ha}^{-1}\right)$ and straw yield $\left(5644 \mathrm{~kg} \cdot \mathrm{ha}^{-1}\right)$ of wheat crop.

Maximum plant height, thousand grains weight and spike length of wheat were recorded by the application of sulphur with compost.

Plant $\mathrm{N}$ and $\mathrm{P}$ uptake of wheat crop improved significantly by the addition of $\mathrm{S}$ with compost.

> Micro nutrients ( $\mathrm{Zn}, \mathrm{Cu}, \mathrm{Fe}$ and $\mathrm{Mn}$ ) uptake by wheat plants significantly increased by $\mathrm{S}$ application with compost.

> Post harvest soil total N, OM, and AB-DTPA extractable P contents improved by the addition of $\mathrm{S}$ with compost.

\section{Recommendations}

Following recommendations could be drawn on basis of findings of the conducted research work.

Sulphur application with compost prepared with RP has the potential to improve yield, yield components and nutrients uptake of crops.

Further research work is needed to conduct experiment on sulphur application with composts of different crops and organic materials at various agroecological conditions of Pakistan

\section{References}

[1] Chavarria, J.M. (1981) Hand Book on Phosphate Fertilizers. ISMAN Limited, Paris.

[2] Barbers, S.A. (1995) Soil Nutrient Bioavailability: A Mechanistic Approach. John Wiley and Sons, Fertilizers Development, New York Bio-Fertilizers, 36-51.

[3] Sharif, Z.M., Aslam, M., Baig, M.B. and Ali, A. (2000) Fertility Issues and Fertilizer Management in Rice Wheat System. Quarterly Science, 5, 59-73.

[4] Aslam, M., Khan, M.A., Awan, I.U., Khan, E.A., Khan, A.A. and Jilani, G. (2011) Effect of Single and Combined Use of Various Organic Amendments on Wheat Grown over Green Manured Soil: I. Growth and Yield Attributes. Pakistan Journal of Nutrition, 10, 640-646. https://doi.org/10.3923/pjn.2011.640.646

[5] Shaheen, A., Naeem, M.A., Shafiq, M. and Jilani, G. (2011) Restoring the Land Productivity through Soil Water Conservation and Improved Fertilizer Application in Eroded Land of Pothwar Plateau in Punjab Province, Pakistan. Plant Production Science, 14, 196-201. https://doi.org/10.1626/pps.14.196

[6] Mtengetia, E.E., Semoka, J.M.R. and Maliondoa, S.M. (2013) Assessment of Maize Response to Minjingu Phosphate Rock and Triple Superphosphate Applied under Different Application Strategies in a Ferral Soil in Tanzania. Archives of Agronomy and Soil Science, 59, 1323-1338. https://doi.org/10.1080/03650340.2012.721540

[7] Nelson, D.W. and Sommer, L.E. (1996) Total C, Organic C and Organic Matter. In: Spark, D.L., Ed., Method of Soil Analysis, Part 3, American Society of Agronomy, Vol. 34, 961-1010. 
[8] Okalebo, J.R., Woomer, P.L., Mukhwana, E.J., Musyoka, M.W., Ndungu, K.W., Kifuko, M.N. and Kiraithe, C.K. (2003) Evaluation of Soil Fertility Management Technologies (Best Bets) on Yield and Uptake of Nitrogen and Phosphorus by Maize and Legumes in Western Kenya: A Six NGO Study. African Crop Science Conference Proceedings, 6, 480-488.

[9] Vanlauwe, B., Tittonell, P. and Mukulama, J. (2006) Within-Farm Soil Fertility Gradients Affect Response of Maize to Fertilizer Application in Western Kenya. Nutrient Cycling in Agroecosystems, 76, 171-182. https://doi.org/10.1007/s10705-005-8314-1

[10] Datta, M., Banik, S. and Gupta, K.K. (1982) Studies on the Efficacy of a Phytohormone Producing Phosphate Solubilizing Bacillus Firmus in Augmenting Paddy Yield in Acid Soils of Nagaland. Plant and Soil, 69, 365-373. https://doi.org/10.1007/BF02372457

[11] Bagavathiammal, U. and Mahimairaja, S. (1999) Use of Tunisia Rock Phosphate with Organics on Typic Inceptisol for Cotton and Green Gram. The Madras Agricultural Journal, 86, 149-151.

[12] DeKok, L.J., Castro, A., Durenkamp, M., Stuiver, C.E.E., Westerman, S., Yang, L. and Stulen, I. (2002) Sulphur in Plant Physiology. Proceedings No. 500, The Inter. Fertiliser Soc. York, 1-26.

[13] Duke, S.H. and Reisenaue, H.M. (1986) Roles and Requirements of Sulfur in Plant Nutrition. In: Tabatabai, M.A., Ed., Sulfur in Agriculture, Agronomy Series No. 27, American Society of Agronomy, Madison, 124-168.

[14] Erdal, I., Kepenek, K. and Kizilgoz, I. (2006) Effect of Elemental Sulfur and Sulfur Containing Waste on Their on Nutrition of Strawberry Plants Grown in a Calcareous Soil. Biological Agriculture \& Horticulture, 23, 263-272. https://doi.org/10.1080/01448765.2006.9755328

[15] Johnson, J.W. (1999) Most Asked Agronomic Questions. In: Johnson, J.W. and Hudak, C., Eds., Ohio State University Extension, Extension Bulletin E-760-88, The Ohio State University, Columbus.

[16] Ali, R., Khan, M.J. and Khattak, R.A. (2008) Response of Rice to Different Sources of Sulfur (S) at Various Levels and Its Residual Effect on Wheat in Rice-Wheat Cropping System. Soil \& Environment, 27, 131-137.

[17] Wells, B.R., Bacon, R.K., Sabbe, W.E. and Sutton, R.L. (1986) Response of Sulfur Deficient Wheat to Sulfur Fertilizer. Journal of Fertility, 3, 72-74.

[18] Mahler, R.J. and Maples, R.L. (1986) Response of Wheat to Sulfur Fertilization. Communications in Soil Science and Plant Analysis, 17, 975-988. https://doi.org/10.1080/00103628609367766

[19] Khalid, R., Khan, K.S., Yousaf, M., Shabbir, G. and Subhani, A. (2009) Effect of Sulfur Fertilization on Rapeseed and Plant Available Sulfur in Soils of Pothwar, Pakistan. Sarhad Journal of Agriculture, 25, 65-71.

[20] Scott, N.M., Dyson, P.W., Roms, J. and Sharp, G.S. (1984) The Effect of Sulfur on the Yield and Chemical Composition of Winter Barley. The Journal of Agricultural Science, 103, 699-702. https://doi.org/10.1017/S0021859600043823

[21] Conry, M.J. (1993) Response of Winter Barley Grown on Two Contrasting Soils on Ireland to Foliar- and Soil-Applied Sulphur. Irish Journal of Agricultural and Food Research, 32, 177-183.

[22] Kettlewell, P.S., Griffiths, M.W. and Hocking, T.J. (1998) Dependence of Wheat Dough Extensibility on Flour S and Nitrogen Concentrations and the Influence of Foliar-Applied S and Nitrogen Fertiliser. Journal of Cereal Science, 28, 15-23. https://doi.org/10.1006/jcrs.1997.0181 
[23] Hussain, N., Hassan, G., Arshadullah, M. and Mujeeb, F. (2001) Evaluation of Amendments for the Improvement of Physical Properties of Sodic Soil. International Journal of Agriculture and Biology, 3, 319-322.

[24] Hussain, N.G., Hassan, A.G. and Sarwar, G. (1998) Biomelioration of Sandy Clay Loam Saline Sodic Soil. Proceedings of 6th Micro Irrigation Cong., 8-10 March 1998, 293-300.

[25] Singh, R.D. and Yadav, D.V. (1986) Evaluation of Low Grade Rock Phosphate Composted with Some Agricultural Wastes for Use in a Crop Rotation. Agricultural Wastes, 18, 73-79. https://doi.org/10.1016/0141-4607(86)90109-5

[26] Jagadeeswari, P.V. and Kumaraswamy, K. (2000) Long-Term Effects of Manure Fertilizer Schedules on the Yield of and Nutrient Uptake by Rice Crop in a Permanent Manurial Experiment. Journal of the Indian Society of Soil Science, 48, 833-836.

[27] USDA (2006) Composition of Foods: Raw, Processed, Prepared. USDA National Nutrient Database for Standard, Reference, Release 19, U.S. Dept. of Agric. Beltsville.

[28] MNFSR (2016) Govt. of Pakistan, Ministry of National Food Security \& Research.

[29] McClean, E.O. (1982) Soil pH and Lime Requirement. In: Page, A.L., Miller, R.H. and Keeny, D.R., Eds., Methods of Soil Analysis, Part 22nd Edition, American Society of Agronomy, Vol. 9, 199-208, 209-223.

[30] Richards, L.A. (1954) Diagnosis and Improvement of Saline and Alkali Soils. U.S. Dept. Agricultural Handbook, Vol. 60, 110-118.

[31] Black, C.A., Evans, D.D. and Dinauer, R.C. (1965) Methods of Soil Analysis. Vol. 9, American Society of Agronomy, Madison.

[32] Bremner, J.M. and Mulvaney, C.S. (1996) Kjeldhal Method. In: Method of Soil Analysis Part-2: Chemical \& Microbiological Properties, American Society of Agronomy, Madison, 903-948.

[33] Soltanpour, P.N. and Schwab, A.P. (1977) A New Soil Test for Simultaneous Extraction of Macro and Micro Nutrients in Alkaline Soils. Communications in Soil Science and Plant Analysis, 8, 195-207. https://doi.org/10.1080/00103627709366714

[34] Gupta, V.K., Sanjeev, K. and Singh, A.K. (2004) Yield and Quality of Wheat (Triticum aestivum) as Influenced by Sulphur Nutrition and Weed Management. Indian Journal of Agricultural Sciences, 74, 254-256.

[35] Zhang, Z.Y., Sun, K.G., Lu, A.Y. and Zhang, X.B. (1999) Study on the Effect of S Fertilizer Application on Crops and the Balance of S in Soil. The Journal of Agricultural Science, 5, 25-27.

[36] Prasad, B. (2003) Effect of Direct and Residual Effects of Different S Fertilizers on Groundnut and Wheat Cropping System on Typic Haplaquent Soils. Journal of Plant Nutrition, 26, 997-1008. https://doi.org/10.1081/PLN-120020071

[37] Kucy, R.M.N. (1987) Increased P Uptake by Wheat \& Soyabean Application with RP Inoculated with P Solubilizing Microorganisms. Environmental Microbiology, 52, 2699-2703.

[38] Ibrahim, M., Anwar-ul-Hassan, M.I. and Valeem, E.E. (2008) Response of Wheat Growth and Yield to Various Levels of Compost and Organic Manure. Pakistan Journal of Botany, 40, 2135-2141.

[39] Phiri, A.T., Joyce, P.N., George, Y.K., Sieglinde, S. and Max, W.L. (2010) Maize Yield Response to the Combined Application of Tundulu Rock Phosphate and Pigeon Pea Residues in Kasungu, Central Malawi. African Journal of Agricultural Re- 
search, 5, 1235-1242.

[40] Soleimani, R. (2006) The Effect of Integrated Application of Micronutrient on Wheat in Low Organic Carbon Conditions of Alkaline Soil of Western Iran. 18th World Congress of Soil Science, 22.

[41] Majumdar, B., Venkatesh, M.S., Kumar, K. and Patiram (2007) Effect of Rock Phosphate, Superphosphate and Their Mixtures with FYM on Soybean and Soil-P Pools in a Typic Hapludalf of Meghalaya. Journal of the Indian Society of Soil Science, 55, 167-174.

[42] Khan, A., Jan, M.T., Marwat, K.B. and Arif, M. (2009) Organic and Inorganic Nitrogen Treatments Effects on Plant and Yield Attributes of Maize in a Different Tillage Systems. Pakistan Journal of Botany, 41, 99-108.

[43] Shah, Z. and Ishaq, M. (2006) Effect of Integrated Use of Farm Yard Manure and Urea on Yield and Nitrogen Uptake of Wheat. Journal of Agricultural and Biological Sciences, 1, 356-360.

[44] Ahmad, R., Arshad, M., Naveed, M., Zahir, Z.A., Sultan, T. and Khalid, M. (2009) Carbon Mineralization Rate of Composted and Raw Organic Wastes and Their Implications on Environment. Soil \& Environment, 26, 92-96.

[45] Togay, Y., Togay, N., Cig, F., Erman, M. and Celen, A.E. (2008) The Effect of Sulphure Applications on Nutrient Composition, Yield and Some Yield Components of Barley. African Journal of Biotechnology, 7, 3255-3360.

[46] Akhtar, M.J., Asghar, H.N., Asif, M. and Zahir, Z.A. (2007) Growth and Yield of Wheat as Affected by Compost Enriched with Chemical Fertilizer, 1-tryptophan and Rhizobacteria. Pakistan Journal of Agricultural Sciences, 44, 136-140.

[47] Dixit, K.G. and Gupta, B.R. (2000) Effect of Farmyard Manure, Chemical and Biofertilizers on Yield and Quality of Rice (Oryza sativa L.) and Soil Properties. Journal of the Indian Society of Soil Science, 48, 773-780.

[48] Selvakumari, G., Baskar, M., Jayanthi, D. and Mathan, K.K. (2000) Effect of Integration of Flyash with Fertilizers and Organic Manures on Nutrient Availability, Yield and Nutrient Uptake of Rice in Alfisols. Journal of the Indian Society of Soil Science, 48, 268-278.

[49] Khoshgoftarmanesh, A.H. and Kalbasi, M. (2002) Effect of Municipal Waste Leachate on Soil Properties and Growth and Yield of Rice. Communications in Soil Science and Plant Analysis, 33, 2011-2020. https://doi.org/10.1081/CSS-120005745

[50] Jones, C.A., Jacobsen, J.S. and Mugaas, A. (2007) Effect of Low-Rate Commercial Humic Acids on Phosphorus Availability, Micronutrient Uptake, and Spring Wheat Yield. Communications in Soil Science and Plant Analysis, 38, 921-933. https://doi.org/10.1080/00103620701277817

[51] Oates, K.M. and Kamprath, E.J. (1985) Sulfur Fertilization of Winter Wheat Grown on Deep Sandy Soils. Soil Science Society of America Journal, 49, 925-927. https://doi.org/10.2136/sssaj1985.03615995004900040027x

[52] Luo, C., Branlard, G., Griffen, W.B. and McNeil, D.L. (2000) The Effect of N and S Fertilization and Their Interaction with Genotype on Wheat Glutenins and Quality Parameters. Journal of Cereal Science, 31, 185-194. https://doi.org/10.1006/jcrs.1999.0298

[53] Coale, F.J., Costa, J.M., Bollero, G.A. and Schlosnagle, S.P. (2002) Small Grains Winter Cover Crops for Conservation of Residual Soil $\mathrm{N}$ in the Mid-Atlantic Coastal Plain. American Journal of Agricultural Economics, 16, 66-72.

[54] Soylu, S., Sade, B., Topal, A., Akgun, N. and Gezay, S. (2005) Response of Irrigated 
Durum and Bread Wheat Cultivars to Boron Application to Low Boron Calcarious Soil. Turkish Journal of Agriculture and Forestry, 29, 275-286.

[55] Ulukan, H. (2008) Effect of Soil Applied Humic Acid at Different Sowing Times on Some Yield Components in Wheat (Triticum spp.) Hybrids. International Journal of Botany, 4, 164-175. https://doi.org/10.3923/ijb.2008.164.175

[56] Bajpai, R.K., Upadhyay, S.K., Joshi, B.S. and Tripathi, R.S. (2002) Productivity and Economics of Rice (Oryza sativa L.)-Wheat (Triticum aestivum L.) Cropping System under Integrated Nutrient Supply Systems. Indian Journal of Agronomy, 47, 20-25.

[57] Pooran, C., Singh, P.K., Govardhan, M. and Chand, P. (2002) Integrated Management in Rainfed Castor (Ricinus communis). Indian Programs Agriculture, 2, 122-124.

[58] Okalebo, J.R., Othieno, C.A., Woomer, P.L., Karanja, N.K., Semoka, J.R.M., Bekunda, M.A., Mugendi, R.M., Batino, A. and Mukhwana, E.J. (2006) Available Technologies for Replenishing Soil Fertility in Africa. Nutrient Cycling in Agroecological Systems, 76, 153-170. https://doi.org/10.1007/s10705-005-7126-7

[59] Miller, J.R. (1965) Effect of Sulfur and Gypsum Addition on Availability of Rock Phosphate. Soil Science, 82, 129-134.

[60] Gunes, A., Inal, A., Bagci, E.G., Kadioglu, Y.K. and Eraslan, F. (2008) Variations in Essential and Non-Essential Element Composition and Yield of Silage Corn Fertilized with Sulfur. Journal of Plant Interactions, 3, 181-188. https://doi.org/10.1080/17429140701799646

[61] Kaplan, M. and Orman, S. (1998) Effect of Elemental Sulfur and Sulfur Containing Waste in a Calcareous Soil in Turkey. Journal of Plant Nutrition, 21, 1655-1665. https://doi.org/10.1080/01904169809365511

[62] Parham, J.A., Deng, S.P., Raun, W.R. and Johnson, G.V. (2002) Long-Term Cattle Manure Application in Soil. Biology and Fertility of Soils, 35, 328-337. https://doi.org/10.1007/s00374-002-0476-2

[63] Soaud, A.A., Al-Darwish, F.H., Saleh, M.E., El-Tarabiliy, K.A., Sofian-Azirun, M. and Rahman, M.M. (2011) Effects of Elemental Sulfur, Phosphorus, Micronutrients and Paracoccus versutus on Nutrient Availability of Calcareous Soils. Australian Journal of Crop Science, 5, 554-561.

[64] Ouedraogo, E., Mando, N. and Zombre, P. (2001) Use of Compost to Improve Soil Properties and Crop Productivity under Low Input Agricultural System in West Africa. Agriculture, Ecosystems \& Environment, 84, 259-266. https://doi.org/10.1016/S0167-8809(00)00246-2

[65] Sharif, M., Ahmad, M., Sarir, M.S. and Khattak, R.A. (2004) Effect of Organic and Inorganic Fertilizers on the Yield and Yield Components of Maize. Pakistan Journal of Agricultural Research, 20, 11-16.

[66] Tomayo, V.A., Munoz, A.R. and Diaz, A.C. (1997) Organic Fertilizer Application to Maiz (Zea mays L.) on Alluvial Soil in a Moderate Climate. Actualidades-Corpoica, 108, 19-24.

[67] Sarwar, G. (2005) Use of Compost for Crop Production in Pakistan. Okologie und Umweltsicherung Germany, Vol. 26, 1-203.

[68] Smiciklas, K.D., Walker, P.M. and Kelley, T.R. (2002) Utilization of Compost (Food, Paper, Landscape and Manure) in Row Crop Production Website Reference ww:/E:/utilization\% 20 conipost\% 20 (Food\%20 paper,\%20 lands scape\% $20 \mathrm{M}$ and\% 201 : Department of Agriculture and Health Sciences, Illinois State University. 
[69] Ali, A., Sharif, M., Wahid, F., Zhang, Z., Shah, S.N.M., Rafiullah, Zaheer, S., Khan, F. and Rehman, F. (2014) Effect of Composted Rock Phosphate with Organic Materials on Yield and Phosphorus Uptake of Berseem and Maize. American Journal of Plant Sciences, 5, 975-984. https://doi.org/10.4236/ajps.2014.57110

[70] Hileman, L.H., Crossland, G. and Burr, E. (1980) Performance of Compost in Reclaiming Salt-Damaged Soils. Mimeograph Series 279, Agri. Ata. Exp. Division of Agri., Univ. of Arkansas, Fayetteville, 1-9.

[71] Singh, M., Singh, V.P. and Reddy, K.S. (2001) Effect of Integrated Use of Fertilizer Nitrogen and Farmyard Manure or Green Manure on Transformation of N, K and S and Productivity of Rice-Wheat System on a Vertisol. Journal of the Indian Society of Soil Science, 49, 430-435.

[72] Bill, A. (2004) Understanding pH Management and Plant Nutrition. International Phalaenopsis Alliance, 13, 500-544.

[73] Meek, B., Graham, L. and Donovan, T. (1982) Long-Term Effects of Manure on Soil Nitrogen, Phosphorus, Potassium, Sodium, Organic Matter, and Water Infiltration Rate. Soil Science Society of America Journal, 44, 1113-1118.

[74] Rautaray, S.K., Ghosh, B.C. and Mittra, B.N. (2003) Effects of Fly Ash, Organic Wastes and Chemical Fertilizers on Yield, Nutrient Uptake, Heavy Metal Content and Residual Fertility in Rice-Mustard Cropping Sequence under Acid Lateritic Soils. Biosource Technologies, 90, 275-283.

https://doi.org/10.1016/S0960-8524(03)00132-9

[75] Esilaba, A.O., Reda, F., Ransom, J.K., Bayu, W., Woldewahid, G. and Zemichael, B. (2000) Integrated Nutrient Management Strategies for Soil Fertility Improvement and Striga Control in Northern Ethiopia. African Crop Science Journal, 8, 403-410. https://doi.org/10.4314/acsj.v8i4.27680

[76] Ayuso, M., Pascual, J.A., Garcia, C. and Hernandez, T. (1996) Evaluation of Urban Wastes for Agricultural Use. Soil Science and Plant Nutrition, 42, 105-111. https://doi.org/10.1080/00380768.1996.10414693

[77] Castellanos, J. and Pratt, P.F. (1981) Mineralization of Manure Nitrogencorrelation with Laboratory Indexes. Soil Science Society of America Journal, 45, 354-357. https://doi.org/10.2136/sssaj1981.03615995004500020025x

[78] Wang, C.M., Changa, C.M., Watson, M.E., Dick, W.A., Chen, Y. and Hoitink, H.A.J. (2004) Maturity Indices of Composted Dairy and Pig Manures. Soil Biology and Biochemistry, 36, 767-776. https://doi.org/10.1016/j.soilbio.2003.12.012

[79] Goodarzi, K. (1994) Study of Sulfur and Compost Effects to Increase Ability of Soil Nutrients Uptake and Wheat Yeild. New Methods of Wheat Feeding (Articles Collections). Department of Agriculture, Office of Wheat Self-Sufficiency, Tehran.

[80] Modaihsh, S., Al-Mustafa, W.A. and Metwally, A.E. (1989) Effect of Elemental Sulfur on Chemical Changes and Nutrient Availability in Calcareous Soils. Plant \& Soil, 116, 95-101. https://doi.org/10.1007/BF02327261

[81] Kittams, H.A. and Attoe, O.J. (1965) Availibility of Phosphorous in Rock Phosphate-Sulfur Fusion. Agronomy Journal, 57, 331-334. https://doi.org/10.2134/agronj1965.00021962005700040006x

[82] Pattanayak, S.K., Mishra, K.N., Jena, M.K. and Nayak, R.K. (2001) Evaluation of Green Manure Crops Fertilized with Various Phosphorus Sources and Their Effect on Subsequent Rice Crop. Journal of the Indian Society of Soil Science, 49, 285-291.

[83] Parmer, D.K. and Sharma, V. (2002) Studies on Long-Term Application of Fertilizers and Manure on Yield of Maize-Wheat Rotation and Soil Properties under 
Rain-Fed Conditions in Western-Himalayas. Journal of the Indian Society of Soil Science, 50, 311-312.

[84] Verma, T.S., Suri, V.K. and Paul, J. (2002) Prescription-Based Fertilizer Recommendations for Rice, Maize and Wheat in Different Agro-Climatic Zones of Himachal Pradesh. Journal of the Indian Society of Soil Science, 50, 272-277.

[85] Awaad, M.S., Azza, A.R. and Bayoumi, M.A. (2009) Effect of Farmyard Manure Combined with Some Phosphate Sources on the Productivity of Canola Plants Grown on a Sandy Soil. Research Journal of Agriculture and Biological Sciences, 5, 1176-1181.

[86] Jan, M.T., Khan, M.J., Khan, A., Arif, M., Shafi, M. and Farmanullah (2010) Wheat Nitrogen Indices Response to Nitrogen Source and Application Time. Pakistan Journal of Botany, 42, 4267-4278.

[87] Taalab, A.S., Hella, F.A. and Abou-Seeda, M.A. (2008) Influence of Phosphate Fertilizers Enriched with Sulfur on Phosphorus Availability and Corn Yield in Calcareous Soil in Arid Region. Ozean Journal of Applied Sciences, 1, 105-115.

[88] Besharati, H. (1998) The Effect of Sulfur with Thiobacillus Species to Increase Absorbs Some Soil Elements. Thesis Soil Science, Faculty of Agric., Tehran University, $176 \mathrm{p}$.

[89] Yaduvanshi, N.P.S. (2001) Effect of Five Years of Rice-Wheat Cropping and NPK Fertilizer Use with and without Organic and Green Manures on Soil Properties and Crop Yields in a Reclaimed Sodic Soil. Journal of the Indian Society of Soil Science, 49, 714-719.

[90] Eghball, B. (2003) Leaching of Phosphorus Fraction Following Manures and Compost Application. Communications in Soil Science and Plant Analysis, 34, 2803-2815. https://doi.org/10.1081/CSS-120025207

[91] Kayser, A., Wenger, K., Keller, A., Attinger, W., Felix, H.R., Gupta, S.K. and Schulin, R. (2000) Enhancement of Phytoextraction of $\mathrm{Zn}, \mathrm{Cd}$, and $\mathrm{Cu}$ from Calcareous Soil: The Use of NTA and Sulfur Amendments. Environmental Science \& Technology, 34, 1778-1783. https://doi.org/10.1021/es990697s

[92] Akbarinia, A., Ghalavand, A., Ashorabadi, A.S. and Shfieei, S.B. (2003) Effect of Different Nutrition Systems on Soil Propertis, Elemental Uptake and Seed Yield of Ajowan (Carum Cupticum). Pajouhesh and Sazandegi, 62, 11-29.

[93] Glyn, M.F. (2002) Mineral Nutrition, Production and Artemisin Content in Artemisia Annual. Acta Horticulturae, 426, 721-728.

[94] Tisdale, S.L., Nelson, W.L. and Beaton, J.D. (1984) Soil Fertility and Fertilizers. 4th Edition, Mcmillon Publishing Company, New York.

[95] Clark, R.B. and Zeto, S.Z. (1996) Mineral Acquisition by Mycorrhizal Maize Grown on Acid and Alkaline Soil. Soil Biology and Biochemistry, 28, 1495-1503. https://doi.org/10.1016/S0038-0717(96)00163-0

[96] Siami, A., Besharati, H. and Golchin, A. (2008) Evaluation of Sulfur Oxidation and Its Relationship with Iron and Zink Release in Calcareous Soils. The 10 th Iranian Congress of Soil Science, Karaj, Tehran. 